GROUND-WATER FLOW IN THE NAVAJO SANDSTONE IN PARTS OF EMERY, GRAND, CARBON, WAYNE, GARFIELD, AND KANE COUNTIES, SOUTHEAST UTAH By Emanuel Weiss

U.S. GEOLOGICAL SURVEY

Water-Resources Investigations Report 86-4012 
DEPARTMENT OF THE INTERIOR

DONALD PAUL HODEL, Secretary

U.S. GEOLOGICAL SURVEY

Dallas L. Peck, Director

For additional information write to:

District Chief

U.S. Geological Survey

Water Resources Division

Box 25046, Mail Stop 415

Federal Center

Denver, CO 80225
Copies of this report can be purchased from:

U.S. Geological Survey Books and Open-File Reports Federal Center, Bldg. 810 Box 25425

Denver, CO 80225 
Page

Abstract-1--0.- 1

Introduction---on 2

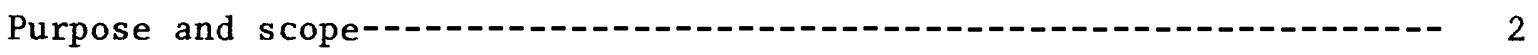

Hydrology---1--

Geologic setting---1-- 6

Description of the computer mode1-- 10

Model characteristics---

Model boundaries---1

Differences between measured and simulated water levels----_--- 15

Statistical evaluation of errors--- 15

Areas where differences between measured and simulated water

levels are greatest-_. 19

Sensitivity analysis-_.

Sensitivity to recharge from Henry Mountains-_.

Sensitivity to hydraulic-conductivity distribution-_._.

Sensitivity of calibration to changes on northern boundaries-.-.-.-- 26

Magnitudes and directions of simulated flow- 26

Differences between simulated water levels caused by grid-size reduction-- 31

Flow due to density differences-_... 35

Summary and conclusions-_. 39

References-_. 40

\section{FIGURES}

Figures 1-2. Maps showing:

1. Location of modeled area and lines of stratigraphic cross sections -...- 3

2. Areal distribution of precipitation-_. 5

3-4. Stratigraphic cross sections showing:

3. Geologic section A-A' of San Rafael Swel1-n 8

4. Geologic section B-B' of Mount Pennel1-... 9

5-12. Maps showing:

5. Model grid of active nodes and special function nodes--- 12

6. Distribution of water-level measurements in the Navajo Sandstone and model perimeter-...- 14

7. Final calibrated potentiometric surface with associated water-table nodes-_... 16

8. Histogram of calibration residuals_..... 20

9. Thickness of Navajo Sandstone used in mode1-.....-- 21

10. Distribution of hydraulic conductivity used in mode1--- 24

11. Structure contours on the top of the Navajo Sandstone--- 25

12. Simulated flow through sides of selected rectangular areas...... 28

13. Differences in simulated water levels caused by grid-size reduction in the northeast corner of model grid-...-.- 33

14. Typical changes in simulated water levels caused by gridsize reduction near the San Rafael Swel1-_... 34 


\section{TABLES}

Page

Table 1. Comparison between measured and simulated hydraulic heads------ 17

2. Simulated and estimated values of major recharge and major simulated discharge---_- 30

3. A comparison between hydraulic heads simulated using a fine and a coarse model grid for the northeast corner of the modeled area-- 36

CONVERSION FACTORS

For use of readers who prefer to use metric units, conversion factors for terms used in this report are listed below:

\section{Multiply}

cubic foot per second $\left(\mathrm{ft}^{3} / \mathrm{s}\right)$

foot $(f t)$

foot per second $(\mathrm{ft} / \mathrm{s})$

foot per day $(\mathrm{ft} / \mathrm{d})$

foot squared per second $\left(\mathrm{ft}^{2} / \mathrm{s}\right)$

inch (in.)

inch (in.)

mile (mi)

pound per cubic foot $\left(1 \mathrm{~b} / \mathrm{ft}^{3}\right)$

square foot $\left(\mathrm{ft}^{2}\right)$

square mile $\left(\mathrm{mi}^{2}\right)$

U.S. gallons per minute (gal/min)
By

0.02832

0.3048

0.3048

0.3048

0.0929

25.40

2.540

1.609

16.02

0.0929

2.590

$6.309(10)^{-5}$
To obtain

cubic meter per second meter

meter per second

meter per day

meter squared per second

millimeter

centimeter

kilometer

kilogram per cubic meter

square meter

square kilometer

cubic meters per second 


\title{
GROUND-WATER FLOW IN THE NAVAJO SANDSTONE IN PARTS OF EMERY, GRAND, CARBON, WAYNE, GARFIELD, AND KANE COUNTIES IN SOUTHEAST UTAH
}

By Emanuel Weiss

\author{
ABSTRACT
}

\begin{abstract}
Water shortages are expected in the Upper Colorado River Basin because of increasing water demands. Management of a ground-water resource can be aided by the use of digital computer models. The initial computer model of the Upper Colorado River Basin Regional Aquifer-System Analysis is the twodimensional, finite-difference, ground-water flow model discussed in this report. The aquifer that was modeled is the Navajo Sandstone of Jurassic and Triassic(?) age, which is located around San Rafael Swell and extends south to Lake Powell. This aquifer is a widely used source of ground water throughout most of the Colorado Plateau. Despite undergoing more extensive study and data collection than most aquifers in the region, it still has many unknown aspects.
\end{abstract}

The simulation described herein is a steady-state representation of the aquifer's flow system, consistent with measured water levels and measured hydraulic conductivities of 1 to 2 feet per day. Flow is simulated from San Rafael Knob, a major recharge area, to the north and south around San Rafael Swell to the east side of the swell. No recharge enters the east rim of San Rafael Swe11. The largest amount of recharge enters exposed Navajo Sandstone at Waterpocket fold. Ground water from Waterpocket fold moves south toward the Colorado River and east toward Dirty Devil Canyon discharging at these two locations. All simulated flows, recharge, and discharge are quantified.

Sensitivity of the simulated flow to changes within the range of uncertainty of hydraulic-conductivity distribution, recharge, and boundary flow is reported. Large uncertainties in quantity and location of recharge make the simulation most sensitive to these two factors. Because there are not enough hydraulic-head measurements west of San Rafael Swe11, the model is insensitive to a switch of recharge from San Rafael Knob to the Wasatch Plateau. Error in the simulation due to grid size is estimated. The error due to grid size is comparable to the differences between simulated hydraulic heads and measured hydraulic heads; consequently, additional simulation refinement is worthless.

One of the assumptions included in the model is that the ground water is of constant density. The validity of this assumption was investigated for the area of greatest density variation; the assumption was found to create no larger change in flow than other hydrologic uncertainties in this area. 


\section{INTRODUCTION}

Earlier studies determined that the Navajo Sandstone supplied water to many parts of the Colorado Plateau, a part of the Upper Colorado River Basin (Marine, 1962). Later development near Caineville indicated that large quantities of water potentially could be obtained from the Navajo Sandstone. Approximately 3,000 gal/min came from two wells near Caineville (Hood and Danielson, 1979).

This report discusses the initial aquifer simulation in the Upper Colorado River Basin Regional Aquifer-System Analysis (RASA). A part of the ground-water system, the Navajo aquifer in southeast Utah (fig. 1), was selected for modeling because it is one of the better-studied and most-used aquifers. The quantity, availability, and distribution of hydrologic data in southeast Utah for the Navajo aquifer is still inadequate to build an unambiguous model. The area of study includes natural hydrologic boundaries over 70 percent of its perimeter.

\section{Purpose and Scope}

Drought and periods having large precipitation change the quantity and flow patterns of ground-water systems. Withdrawals by development and injection for storage also change ground-water systems. The model described here can be used to estimate the effects of these changes on the ground-water system in the Navajo Sandstone, but a model with smaller grid cells should be used when errors of $70 \mathrm{ft}$ in predicted water levels or errors of 50 percent in recharge and discharge cannot be tolerated. It should be noted that no upper bound on the error inherent in the model has been established, but an error estimate of $70 \mathrm{ft}$ in water levels and 50 to 75 percent in recharge and discharge is presented.

Ground water from the Navajo Sandstone is used moderately by municipal, mining, and agricultural interests. Because of moderate development, drilling for petroleum, and scientific drilling investigations, aquifer characteristics have been defined, and potential reservoirs of ground water have been discovered. To organize these data into a consistent picture of the groundwater system and to investigate the sensitivity of this picture to the uncertainty in data, a model study was begun. Most of the aquifers are in approximate hydrologic equilibrium, and for this condition a steady-state model is appropriate. Because large-scale ground-water development in the region is not planned, simulation of effects of future stresses on the groundwater system is quite speculative and is not described in this report.

Steady-state simulation assumes that influx and efflux for all aquifer elements are equal and that there is no change in storage. The resultant simulation represents the flow balance and available measured water levels and measured hydraulic conductivities of the flow system. Unfortunately, to achieve even an ambiguous picture of the flow system requires more input data than are commonly available. Therefore, estimates and interpolations of hydrologic data need to be made. The result of the modeling effort may or may not decrease the initial uncertainty in the estimates and interpolations. 


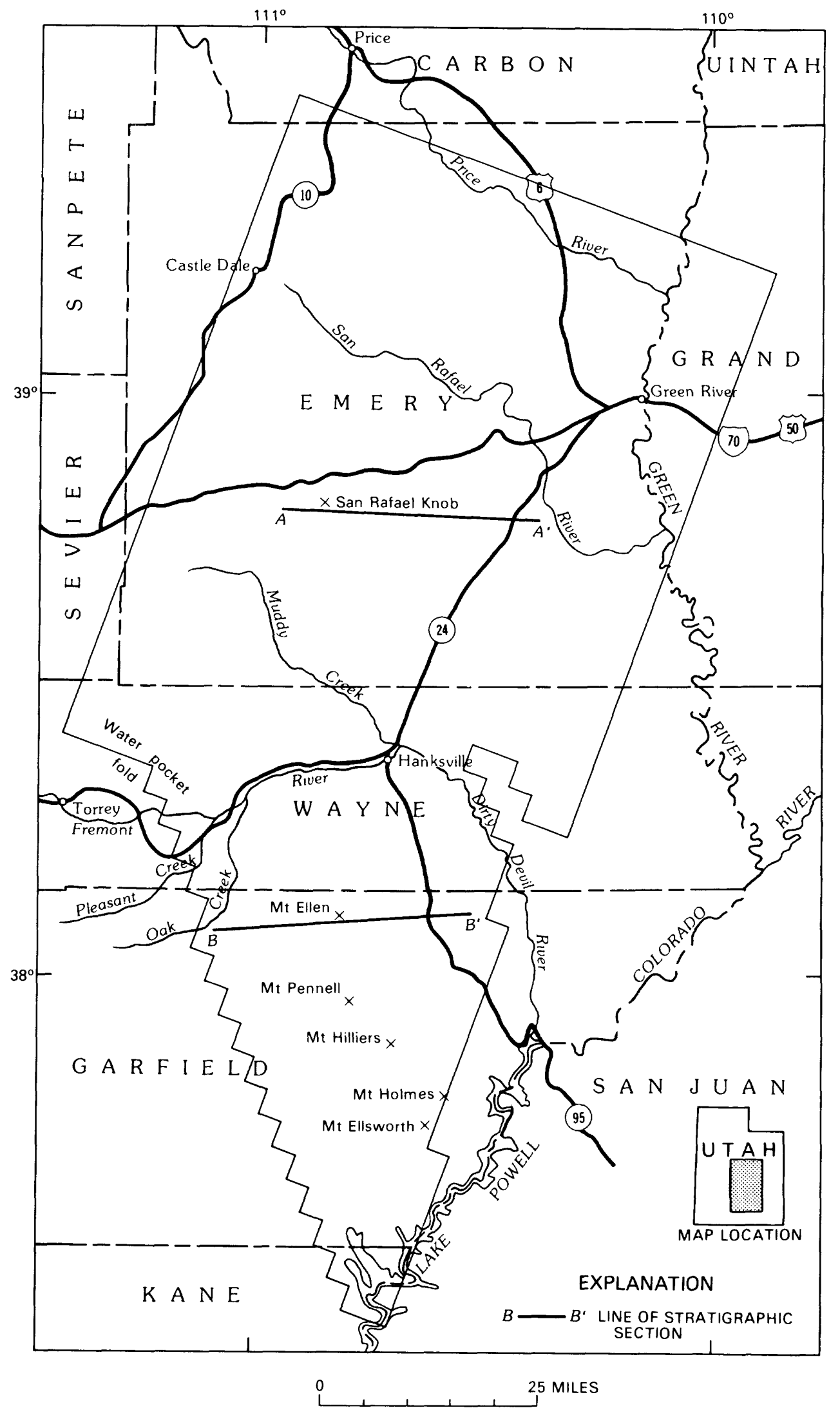

Figure 1.--Location of modeled area and lines of stratigraphic cross sections. 
Sensitivity of the flow pattern to these uncertainties can be determined by model test runs. If a more accurate picture of the flow pattern is desired, then onsite measurements can be made of the hydrologic characteristics to which the model is most sensitive. By using these new onsite measurements in the model, the uncertainty in the initial flow pattern can be reduced. In this way, the model can be an evolutionary product that gives not only a picture of the ground-water flow system but also an indication of the most important unknown characteristics.

\section{HYDROLOGY}

The modeled area is about $7,000 \mathrm{mi}^{2}$ located in the Colorado Plateau in southeast Utah. It is approximately bounded by the Price River on the north, the Colorado River on the south, the Green River on the east, and the Wasatch Plateau and Waterpocket fold on the west (fig. 1). It is a sparsely populated area of fewer than 5,000 people and has only very small quantities of ground water tapped for municipal, mining, and irrigation uses.

Climate ranges from arid to semiarid. At lower altitudes, annual precipitation is less than 6 in.; at higher altitudes, precipitation ranges from 6 to $10 \mathrm{in./yr}$ (fig. 2). In the mountains, annual precipitation can exceed 20 in./yr. Precipitation is quite variable; some snow or rain results from frontal storms from November through April, and the rest of the precipitation results from summer thunderstorms. This variable precipitation causes flow in perennial, intermittent, and ephemeral rivers and streams in the area. The Fremont River, Oak Creek, and Pleasant Creek are the only perennial streams. Muddy Creek and the San Rafael River are intermittent due to agricultural diversion of some of their tributaries during summer.

The headwaters typically are in shallow gullies only a few feet wide and have gradients similar to those of the hill slopes on which they are developed. The low humidity in the region causes some channels to be deep near their headwaters. Streams probably provide recharge where they first cross the outcrop of a permeable rock unit; but where they leave the outcrop the stream surface could be below the water level in the nearby aquifer, and ground water might discharge at the channel surface.

At lower altitudes, some channels cut by surface-water flows become canyons and extend for miles at depths hundreds of feet below the Navajo Sandstone permitting spring flow, evaporation, and transpiration from the canyon walls. Lowland canyons, such as the Dirty Devil River Canyon and the Colorado River Canyon, are sites of large ground-water discharge.

Precipitation infiltrating exposed outcrops is a means of ground-water recharge. The type of precipitation affects the amount of infiltration. The most favorable conditions for recharge are steady precipitation of long duration, low temperatures, and low evaporation. Such conditions occur at some of the higher altitudes. Fissured rocks occur in abundance in the Henry Mountains from Mount Ellen to Mount Ellsworth where, although the area of exposed Navajo Sandstone is smal1, recharge leaking through fissures in the overlying rock can be an important source of water for the Navajo Sandstone. 


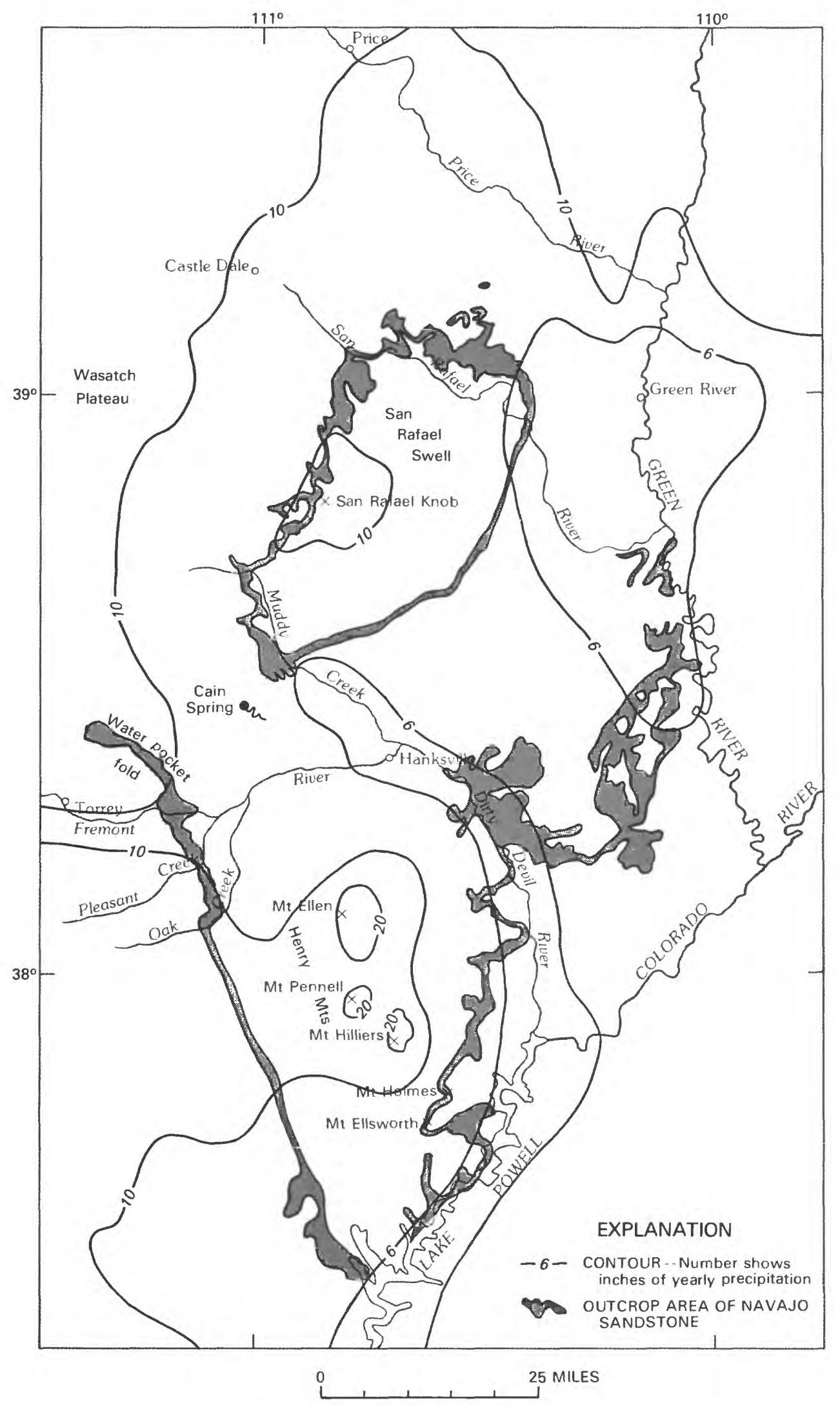

Figure 2.--Areal distribution of precipitation. 
The recharge areas potentially most important for modeling, identified on basis of area of outcrop and precipitation on outcrop area, starting in the southern part of the modeled area, are:

Mounts Holmes and Ellsworth (altitude 8,232 ft) on the southeast border of the modeled area are flanked by approximately $6 \mathrm{mi}^{2}$ of Navajo Sandstone outcrop (not shown in the figures in this report, see Hood, 1980), which receives yearly precipitation of 6 in. (fig. 2).

Mounts Hilliers, Pennell, and Ellen (altitude approximately 11,000 ft) are higher peaks of the Henry Mountains. Formed by igneous intrusives, these mountains have less than $3 \mathrm{mi}^{2}$ of exposed Navajo Sandstone surrounding them (not shown in the figures in this report; see Hood, 1980). These peaks receive 10 to 20 in. of precipitation yearly in the higher altitudes.

Waterpocket fold (altitudes up to $11,000 \mathrm{ft}$ ) is located at the middle of the western border of the area modeled and receives approximately 9 in. of annual precipitation over an outcrop area of $30 \mathrm{mi}^{2}$. The Fremont River, Oak Creek, and Pleasant Creek flow over this outcrop area, and springs occur in the area. The net effect of these surface waters on the local ground-water system is unknown. The bending of the Waterpocket fold and the Teasdale anticline provides the possibility of significant fracturing, enhancing the potential for recharge from precipitation and interformational interchange along the outcrop from Oak Creek to a point approximately $10 \mathrm{mi}$ south of Oak Creek. Farther south from Oak Creek folding is more gentle, and the potential for recharge through fractures is probably reduced.

San Rafael Knob (altitude 7,921 ft) is the highest part of an outcrop area of potentially large recharge. The recharge area extends along the west rim of San Rafael Swell and comprises approximately $32 \mathrm{mi}^{2}$ of exposed Navajo Sandstone.

\section{GEOLOGIC SETTING}

Rocks that underlie or are exposed in the modeled area range in age from Precambrian to Holocene. All the formations in the geologic section contain ground water, but much of the section does not contain usable aquifers.

The Carmel Formation of Jurassic age, which overlies the Navajo Sandstone of Jurassic and Triassic(?) age in most of the area, can receive direct recharge where exposed and locally can interchange water with the Navajo Sandstone. However, a basal siltstone within the Carmel Formation impedes drainage downward. The Carmel Formation contains large quantities of evaporites that contribute to the deterioration of the chemical quality of ground and surface water in the area. The Carmel Formation locally can be a useful aquifer; however, most spring discharges from the Carmel Formation range from seepage to about $20 \mathrm{gal} / \mathrm{min}$ (Hood and Danielson, 1981). 
The Kayenta Formation of Jurassic and Triassic(?) age, which underlies the Navajo Sandstone throughout most of the area, consists of shale, siltstone, and sandstone with minor beds of limestone. The formation is a confining bed. It is characterized by a hydraulic conductivity that is much less than the adjacent sandstone aquifers. This confining bed is 150 to 350 ft thick in the study area.

Although the overlying Carmel Formation and underlying Kayenta Formation have local fractures, faults, changes in lithology, and hiatuses that may permit vertical hydrologic interaction, the Navajo Sandstone will be assumed to be bounded above and below by beds of significantly less hydraulic conductivity.

The Navajo Sandstone is massive and crossbedded. The sandstone is loosely to well cemented, and the grains are well packed. It ranges from $1,500 \mathrm{ft}$ thick near the Waterpocket fold to less than $250 \mathrm{ft}$ in the northeast corner of the modeled area (figs. 1 and 9). The Navajo Sandstone is fine grained with unusually uniform grainsize over large areas and tends to be finer grained and less permeable near the base (Hood, 1980).

Faulting and folding are the principal factors that alter the hydraulic conductivity of the Navajo Sandstone in the San Rafael Swell area. The principal structural feature that distorts the rocks is the large anticlinal fold that comprises San Rafael Swell (fig. 3). The axis of the swell trends northeast-southwest. On the top of San Rafael Swell, younger sediments are eroded, exposing Triassic and Permian rocks. The rocks along the east flank dip steeply with the Navajo Sandstone attaining a maximum dip of 85 degrees. The effect of the folding is fracturing and jointing of the rock causing a probable increase in hydraulic conductivity.

Southwest of San Rafael Swell is the Waterpocket fold, which forms part of Capitol Reef. At the northwest tip of Waterpocket fold in the Thousand Lake Mountain area, approximately horizontal beds of the Navajo Sandstone crop out at an altitude of 9,500 ft. The Navajo Sandstone bends down along Waterpocket fold until, along the axis of the Henry Mountain structural basin, it is at or near sea level. East of the structural basin, the Navajo Sandstone slopes gently upward toward the canyons of the Dirty Devil and Green Rivers where it is exposed at altitudes of 4,000 to 5,000 ft. Superimposed on these large folds are numerous smaller features such as Teasdale anticline and the series of anticlines and synclines between Waterpocket fold and San Rafael Swell.

The southern part of the modeled area's structure is dominated by igneous intrusives that form the Henry Mountains (fig. 4). Igneous rocks are of minimal hydraulic conductivity, but around the intrusives, the sedimentary beds are fractured and faulted, allowing surface-water infiltration and probably substantial interformational movement of ground water. 


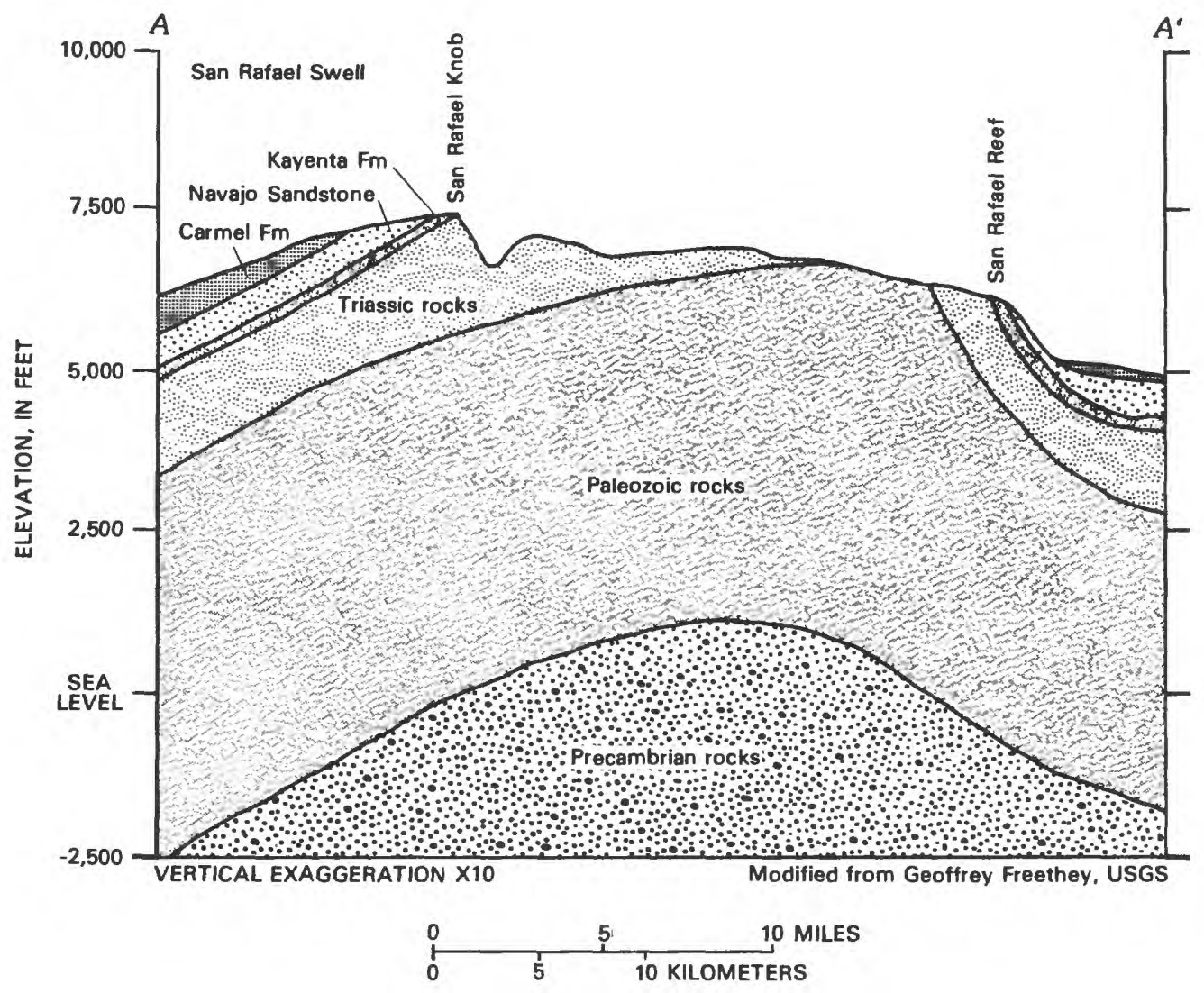

Figure 3.--Geologic section A-A' of San Rafael Swell. 


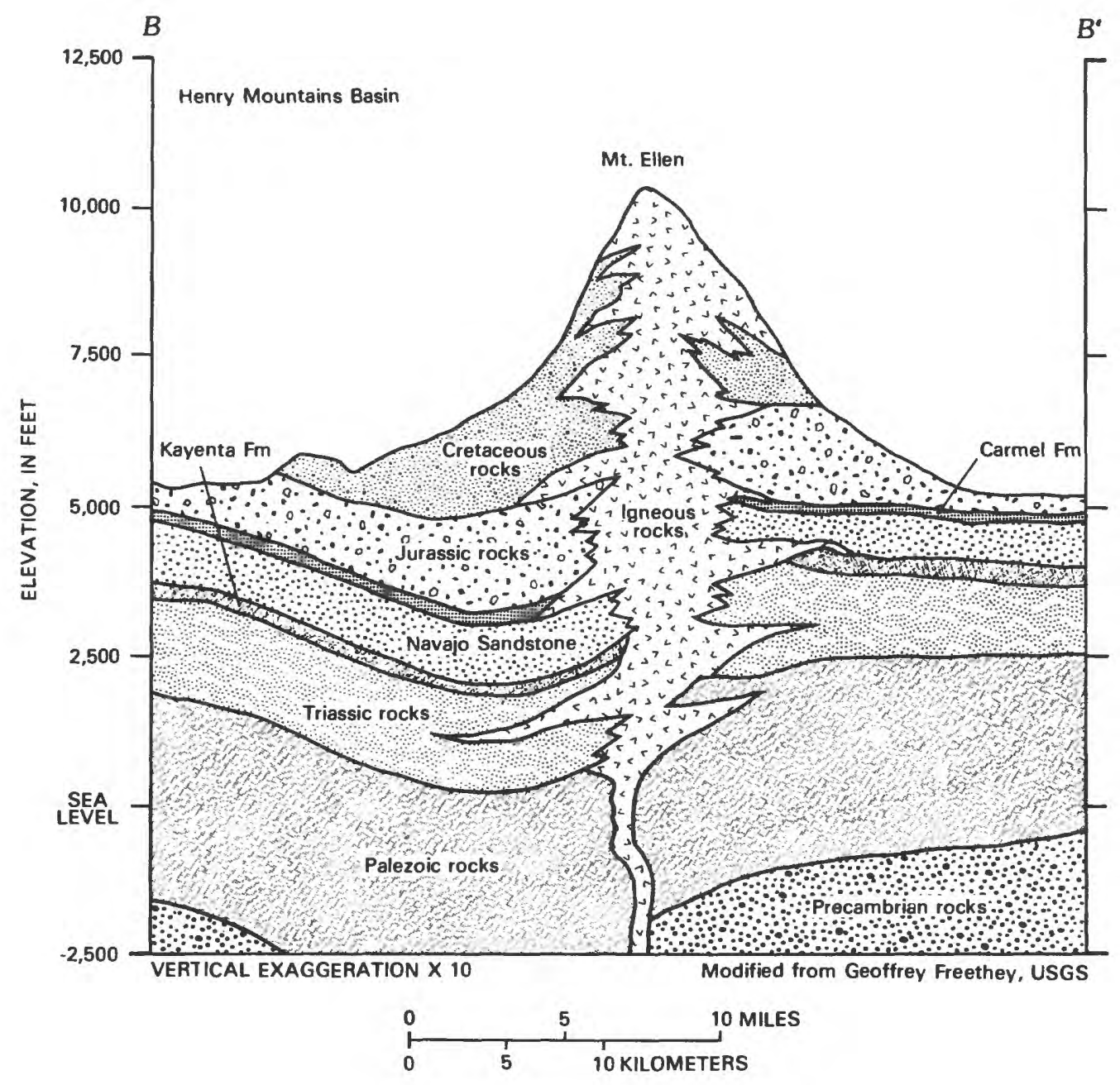

Figure 4.-- Geologic section B-B' of Mount Pennel1. 
The ground-water flow was simulated using a finite-difference model described by McDonald and Harbaugh (1984). To use the model, it is necessary to assume values and trends of hydrologic parameters where they are unknown.

\section{Model Characteristics}

Simple assumptions about hydrologic parameters were adopted; the resulting differences between simulated and measured water levels are approximately equal to the calculational error in the simulated water levels. Thus, complicated assumptions about the hydrologic parameters were not needed because the accuracy of the model calculation made additional simulation refinement worthless.

Some assumptions need to be made when estimating hydrologic characteristics, and some are built into the model. Both types that are used are listed below:

- The ground water has a constant density; and consequently, its flow can be described by Darcy's law (built in);

- The porous medium (the aquifer) and ground water can be considered to be a continuum (built in);

- The system is in steady state; hence, water levels measured at different times are considered to exist at the same time and are used for steady-state calibration;

- There is an isotropic hydraulic-conductivity distribution in the Navajo Sandstone. The model code does not permit local variations in anisotropy (built in);

- The Navajo Sandstone has an impermeable top and bottom except in outcrop areas, in the Henry Mountains, and at Caine Spring. If water leaks into the Navajo Sandstone in other areas and leaks out of the aquifer without much lateral movement, then the head configuration in the area of leakage will not be much affected by such leakage, and this model using an impermeable top and bottom will allow an accurate simulation.

- The nodal cells are small enough for the model to calculate flow accurately;

- Vertical flow within the Navajo Sandstone can be ignored (a simplifying assumption made because of lack of knowledge); and

- Altitude changes of the aquifer have no hydraulic effects; consequently, the aquifer can be modeled as if it were flat. 
To use the finite-difference method, the area is divided into nodal cells each having a node at the center (fig. 5). Twenty nodal cells are in each row and a maximum of 43 nodal cells in a column. The rows all have a width of $3.03 \mathrm{mi}$, and the columns are of variable width but have approximately the same width as the rows. Each cell must be assigned an arbitrary initial water level, a value of hydraulic conductivity, altitudes at the top and bottom of the aquifer, a global anisotropy factor, and sometimes a special function. The special functions (following the designations in McDonald and Harbaugh, 1984) used in this model are:

- Constant head--the head initially assigned remains constant throughout the simulation;

- Well recharge--a specified rate of ground water is injected into the cell;

- Drain--a specified rate of ground water is emitted from the cell;

- General-head boundary and head-dependent boundary--an external head and a hydraulic conductance between the external head and the head of the cell are specified. Water may flow to or from this cell according to the head difference; and

- River--a river-bottom altitude, riverbed conductance, and river-level altitude are specified. This is similar to a head-dependent boundary function.

Once these functions and parameters are assigned to each node, the numerical algorithm (the strongly implicit procedure, SIP) within the Fortran program can be used to calculate head values at each node. The steady-state mode of the program results in the calculation of equilibrium head values, wherein the rate of recharge to the system is the same as the rate of discharge, and no change in head occurs with time.

Because there are no measurements of ground-water recharge for the area, areas of significant recharge were inferred from indirect evidence. Possible recharge areas and their recharge rates were selected on the basis of extent of exposed outcrop area and the amount of yearly precipitation on that area (see previous section entitled "Hydrology"). All possible areas were not necessary for good simulation. The east and northwest rims of the San Rafael Swe11 were candidates but were eliminated when it became apparent that recharge there was not necessary for good calibration. Similarly, the Navajo Sandstone outcrop south of Oak Creek initially was modeled as a recharge area, but the recharge was found to be unnecessary. Location of major recharge areas and rates of recharge attributed to them are major factors affecting calibration, but even here ambiguity is demonstrated because the final calibration was shown to be insensitive to an interchange of an important recharge area and a no-flow boundary. 


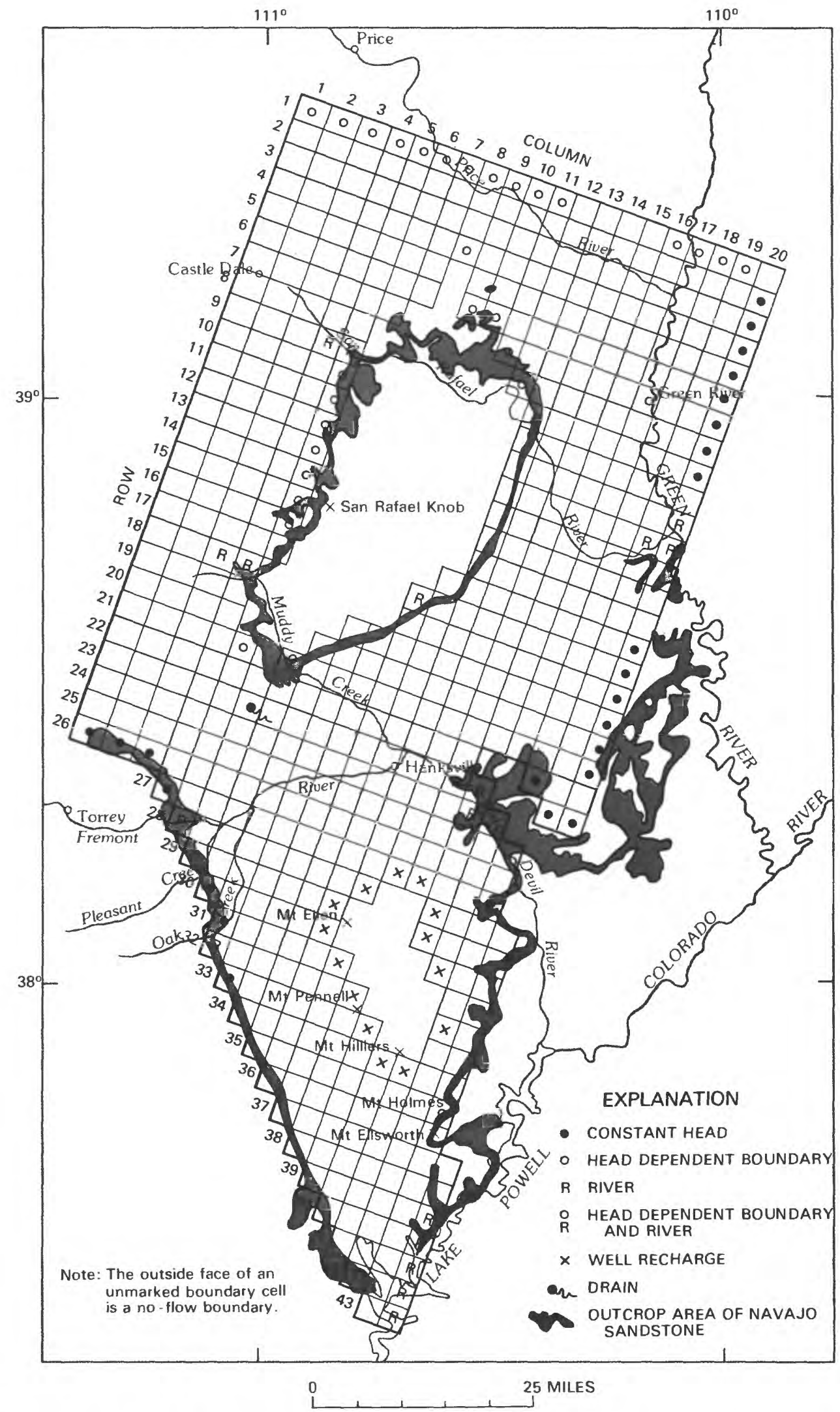

Figure 5.--Model grid of active nodes and special function nodes. 


\section{Mode1 Boundaries}

The constant-head nodes along the east boundary and the general-head boundary nodes along the north boundary simulate flow away from the swell as postulated by Hood and Danielson (1981) and Hood and Patterson (1984). Near both boundaries, water-level measurements are insufficient to determine the shape of the potentiometric surface (fig. 6). These boundaries along row 1 and column 20 north of the San Rafael River are not natural hydrologic boundaries nor are there natural hydrologic boundaries nearby. Ground water might move in or out of these boundaries. From hydraulic head gradients between observation wells in the interior, it seems that these boundaries are largely out-flow boundaries and have been modeled as if they were.

Data are even less abundant for the boundary west of the San Rafael Swell. Along this boundary the possiblity exists that ground water moving east from the Wasatch Plateau and ground water moving west from San Rafael Swel1 flows away from an east-west oriented ground-water divide. If a groundwater divide were between Wasatch Plateau and San Rafael Swell, then little flow probably would occur from one to the other. Also, faults outside the modeled area and east of the Wasatch Plateau parallel the boundary. If these faults were obstacles to flow, then the choice of a no-flow boundary near these faults would be supported. In any case, the simplest choice, consistent with the few measured water levels near the boundary, is a no-flow boundary.

The external boundary west of the Henry Mountains and south of Oak Creek is simulated as a no-flow boundary (fig. 5). Other versions of the model that simulated this as a recharge boundary were abandoned as unnecessarily complicated because they did not result in a better match to field data. Additional water levels in the Navajo Sandstone on and off the outcrop need to be measured before the type of boundary can be determined.

At nodes row 17, column 11, Temple Wash, and row 27, column 18, Poison Spring Canyon, river nodes occur in mostly dry canyons (fig. 5). These simulate discharge through canyon walls by springs, evaporation, and transpiration.

A11 the river nodes are associated with a river or canyon crossing an outcrop. All the specified flux nodes are around the Henry Mountains and simulate recharge from precipitation. A general-head boundary performs the same function in the Mount Holmes area. The general-head boundary nodes around San Rafael Swell, an internal model boundary, are simulating recharge to the ground-water system from precipitation that falls on the Navajo Sandstone outcrop. Constant-head nodes along Waterpocket fold serve a similar function.

The choice of whether a boundary flow needs to be simulated by a generalhead boundary or a constant-head boundary is not critical for an unstressed 


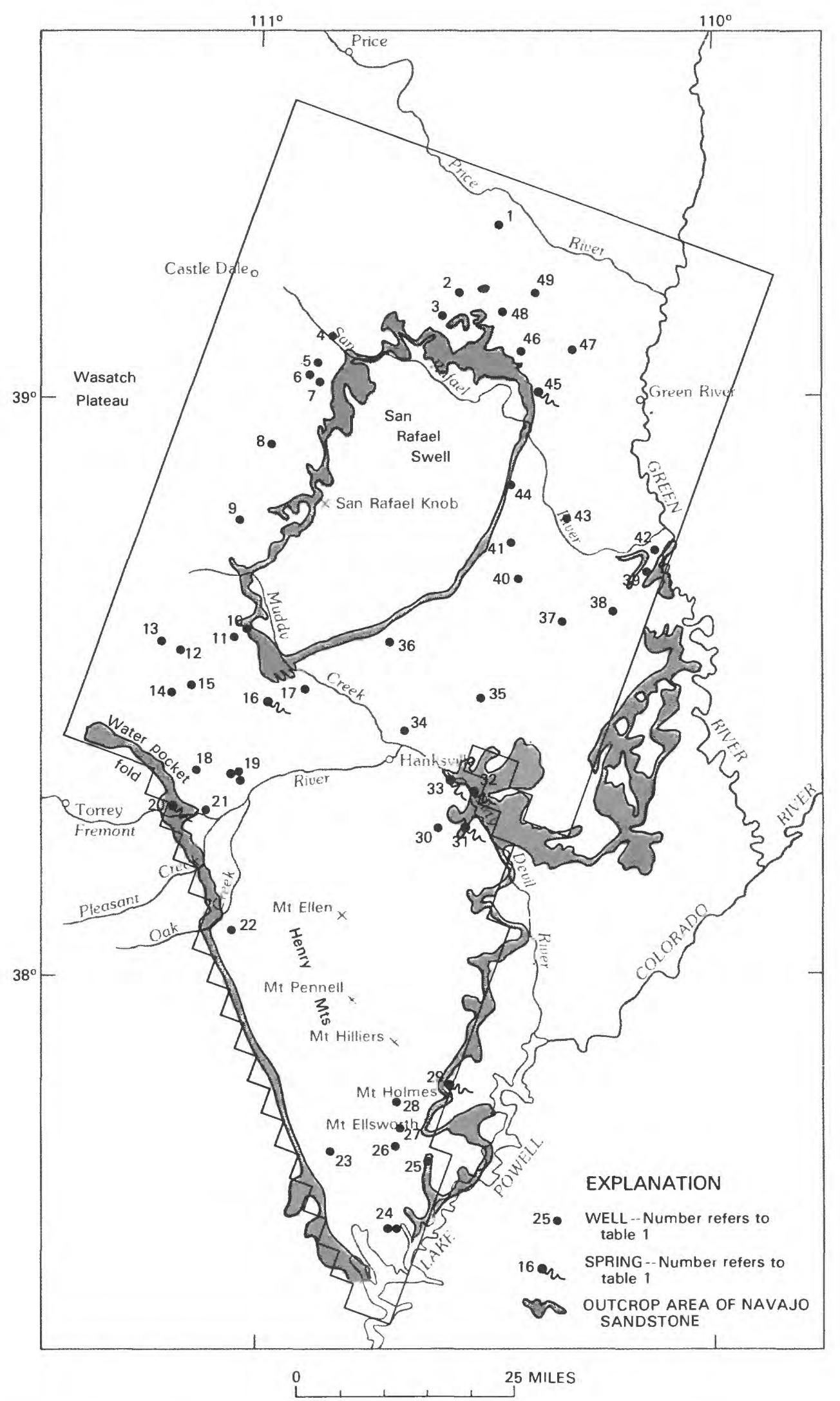

Figure 6.--Distribution of water-level measurements in the Navajo Sandstone and model perimeter. 
steady-state system. For transient and stressed systems the best choice is a general-head boundary. General-head boundaries enable boundary heads to change with transient and stressful conditions. General-head boundaries simulate boundary flow as if there were a constant-head boundary at some distance from the node-defined boundary. The flow from the distant boundary is controlled by the conductance and external head associated with the general-head boundary. Conductance is defined with reference to a crosssectional area of an aquifer, $A$; a distance between two points on a line perpendicular to the cross-sectional area, $\Delta x$; and the effective hydraulic conductivity between the two points, $K$. Conductance is $A K / \Delta x$, which is a convenient coefficient in the finite-difference approximation of Darcy's law (see section entitled "Differences Between Measured and Simulated Water Levels").

For example, all the conductances, C, associated with the general-head boundary nodes in row 1 (fig. 5) are $0.001 \mathrm{ft}^{2} / \mathrm{s}$. Other parameters typical of row 1 are:

$\begin{array}{ll}\text { hydraulic conductivity, } & \mathrm{K}=7 \times 10^{-6} \mathrm{ft} / \mathrm{s}, \\ \text { aquifer thickness, } & \mathrm{d}=250 \mathrm{ft}, \\ \text { node width, } & \Delta \mathrm{x}=3 \mathrm{mi}, \text { and } \\ \text { distance of external head } & \mathrm{Kd} \Delta \mathrm{x} / \mathrm{C} .\end{array}$

The distance from the external head to the node in row 1 is $5 \frac{1}{4} \mathrm{mi}$. Thus, the general-head boundary simulates flow through an extended aquifer that has a boundary a distance of $5 \frac{1}{4} \mathrm{mi}$ beyond the nodes of row 1 .

\section{DIFFERENCES BETWEEN MEASURED AND SIMULATED WATER LEVELS}

Simulated hydraulic heads are shown as a potentiometric surface in figure 7. Measured hydraulic heads from several sources and simulated heads are listed in table 1; altitudes of springs flowing from the Navajo Sandstone also are listed in table 1 . Altitudes of springs are used as minimum values for a local estimate of a hydraulic head measurement.

\section{Statistical Evaluation of Errors}

Simulated heads are at nodes that generally do not coincide with wells or springs; therefore, interpolation often is required to estimate the simulated head at a well or spring site. For example, in table 1 the first site listed is Site $1 W, W$ is for well. This site falls between rows 2 and 3 and between columns 8 and 9 of the finite difference grid; see figures 5 and 6 . Site $1 W$ is at the corner of four nodal cells. This is indicated in the second and third columns of table 1 as Row: $2-3$ and Column: 8-9. The measured head at Site $1 W$ is 5,010 $\mathrm{ft}$. The simulated head is taken to be the average of four heads from the four nodal cells surrounding Site $1 W$. They are the nodes in column 8 and rows 2 and 3 and the nodes in column 9 in rows 2 and 3 . The difference between the measured and simulated water levels is listed in table 1. Some statistical characteristics of these differences and the correlation coefficient between the measured water levels and simulated 


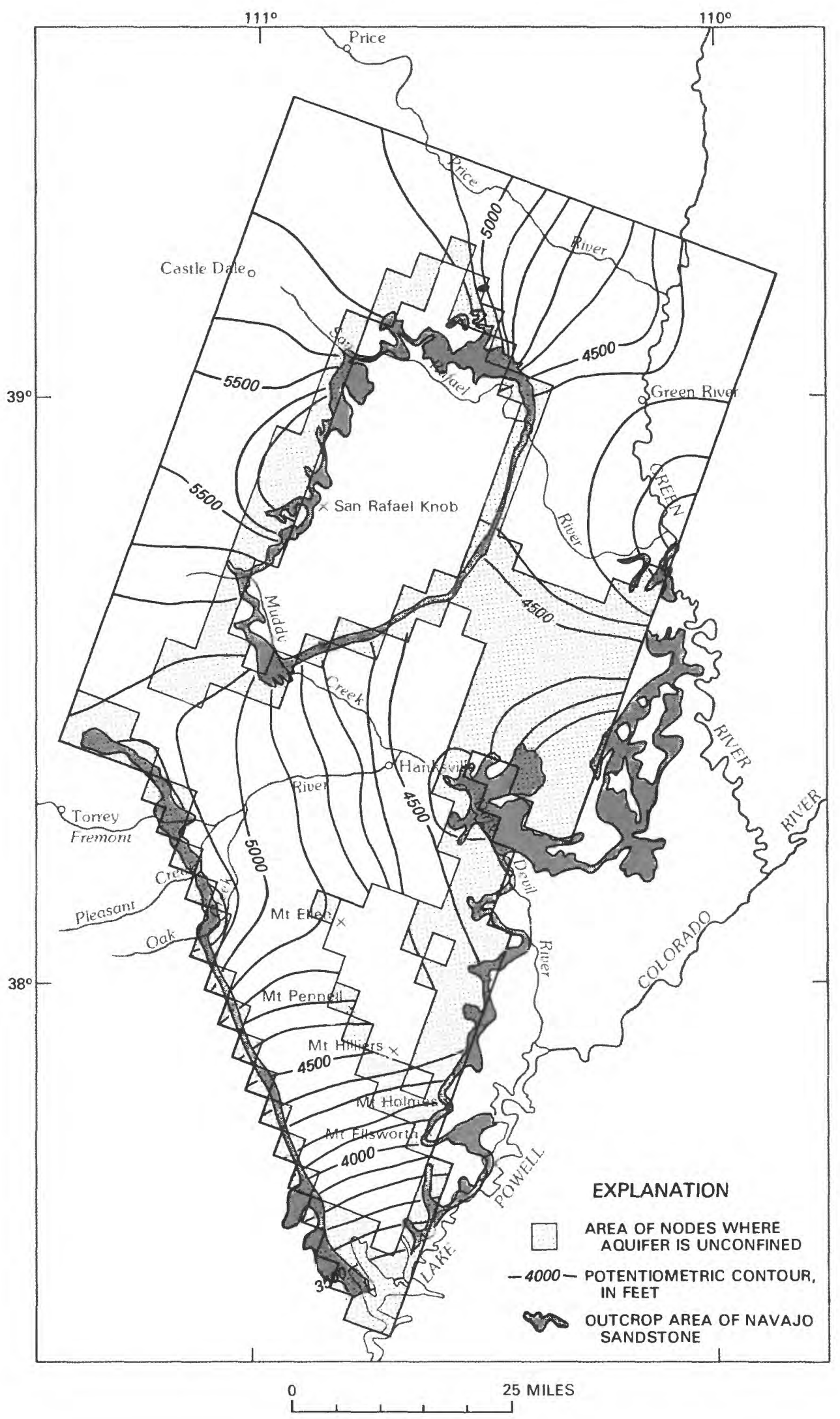

Figure 7.--Final calibrated potentiometric surface with associated watertable nodes. 
Table 1.--Comparison between measured and simulated hydraulic heads

[P, water level reported by company that installed pump; $S$, water level measured by U.S. Geological Survey; D, water level reported by driller; $\mathrm{E}$, water level estimated from incomplete data; $\mathrm{W}$, well; Sp, spring; dashes indicate unavailable data]

\begin{tabular}{|c|c|c|c|c|c|c|}
\hline \multirow[b]{3}{*}{ Site } & \multirow{2}{*}{\multicolumn{2}{|c|}{ Grid }} & \multicolumn{2}{|c|}{ Calibration data } & \multirow{3}{*}{ 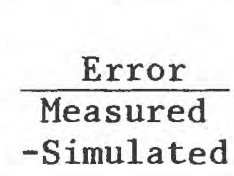 } & \multirow[b]{3}{*}{ Remarks } \\
\hline & & & \multirow{2}{*}{$\frac{\text { Altitude of water }}{\text { Measured }}$} & \multirow{2}{*}{$\frac{\text { level in } \text { feet }^{1}}{\text { Simulated }}$} & & \\
\hline & Row & Column & & & & \\
\hline $1 W$ & $2-3$ & $8-9$ & $5,010 \mathrm{~S}$ & 5,058 & -48 & -- \\
\hline $2 W$ & 6 & 8 & $\begin{array}{l}\text { Dry at } \\
5,514 \mathrm{~S}\end{array}$ & -- & -- & -- \\
\hline $3 W$ & 7 & 8 & $\begin{array}{l}\text { Dry at } \\
5,679 \mathrm{~S}\end{array}$ & -- & $-\cdots$ & -- \\
\hline $4 W$ & 9 & 4 & $5,276 \mathrm{~s}$ & 5,335 & -59 & $\begin{array}{l}\text { In canyon not } \\
\text { representa- } \\
\text { tive of } \\
\text { nodal cell. }\end{array}$ \\
\hline $5 \mathrm{~W}$ & & & & & & Water levels \\
\hline $\begin{array}{l}6 \mathrm{~W} \\
7 \mathrm{~W}\end{array}$ & $10-11$ & 4 & $5,510 \mathrm{D}$ & 5,475 & 35 & $\begin{array}{l}\text { in these } \\
\text { wells are } \\
\text { averaged. }\end{array}$ \\
\hline $8 \mathrm{~W}$ & 14 & 3 & $5,655 \mathrm{D}$ & 5,609 & 46 & -- \\
\hline $9 \mathrm{~W}$ & 17 & 3 & $5,477 \mathrm{D}$ & 5,487 & -10 & -- \\
\hline $10 \mathrm{~W}$ & 21 & 5 & $5,348 \mathrm{D}$ & 5,291 & 57 & -- \\
\hline $11 W$ & 21 & $4-5$ & $5,274 \mathrm{P}$ & 5,296 & -22 & -- \\
\hline $12 W$ & 22 & 3 & $5,220 D$ & 5,218 & 2 & -- \\
\hline $13 W$ & 22 & $2-3$ & $5,241 D$ & 5,229 & 12 & -- \\
\hline $14 \mathrm{~W}$ & 24 & 3 & $5,150 \mathrm{~S}$ & 5,174 & -24 & --- \\
\hline $15 \mathrm{~W}$ & 23 & 4 & $5,072+$ & 5,129 & -57 & --- \\
\hline $16 \mathrm{Sp}$ & 23 & 7 & $4,800^{+} \mathrm{E}$ & 4,880 & -80 & Caine Spring \\
\hline $17 \mathrm{~W}$ & 22 & 8 & $4,615 \mathrm{D}$ & 4,794 & -179 & $\ldots$ \\
\hline $18 \mathrm{~W}$ & 26 & 5 & $5,068 \mathrm{~S}$ & 5,101 & -33 & --- \\
\hline $19 \mathrm{~W}$ & 26 & 7 & $5,007 \mathrm{~S}$ & 5,000 & 7 & $\begin{array}{l}\text { Water levels } \\
\text { in these } \\
\text { four wells } \\
\text { are aver- } \\
\text { aged. }\end{array}$ \\
\hline $20 \mathrm{Sp}$ & 28 & 5 & 5,280 & 5,271 & 9 & $\begin{array}{l}\text { Not in sta- } \\
\text { tistics } \\
\text { because it } \\
\text { is located in } \\
\text { a boundary } \\
\text { node. }\end{array}$ \\
\hline $21 \mathrm{~W}$ & $27-28$ & 6 & $5,088 \mathrm{~S}$ & 5,089 & -1 & --- \\
\hline $22 \mathrm{~W}$ & $31-32$ & 9 & $5,056 \mathrm{P}$ & 5,017 & 39 & --- \\
\hline $23 \mathrm{~W}$ & 38 & 16 & $4,100 \mathrm{E}$ & 4,032 & 68 & -- \\
\hline
\end{tabular}


Table 1.--Comparison between measured and simulated hydraulic heads--Continued

\begin{tabular}{|c|c|c|c|c|c|c|}
\hline \multirow[b]{3}{*}{ Site } & & & \multicolumn{2}{|c|}{ Calibration data } & \multirow{3}{*}{ 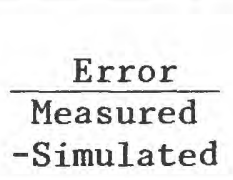 } & \multirow[b]{3}{*}{ Rema rks } \\
\hline & \multicolumn{2}{|c|}{ Grid } & Altitude of water & level in feet & & \\
\hline & Row & Column & Measured & Simulated & & \\
\hline $24 W$ & 40 & $19-20$ & $3,562 \mathrm{~S}$ & 3,490 & 72 & $\begin{array}{l}\text { Water levels } \\
\text { in two wells } \\
\text { are aver- } \\
\text { aged. }\end{array}$ \\
\hline $25 W$ & 37 & 20 & $3,808 \mathrm{D}$ & 3,800 & 8 & --- \\
\hline $26 \mathrm{~W}$ & 37 & $18-19$ & $3,922 \mathrm{~S}$ & 3,950 & -28 & --- \\
\hline $27 W$ & 36 & $18-19$ & $4,027 D$ & 4,108 & -81 & --- \\
\hline $28 W$ & 35 & 18 & $4,350 \mathrm{D}$ & 4,236 & 114 & --- \\
\hline $29 \mathrm{Sp}$ & 34 & $19-20$ & --- & --- & --- & --- \\
\hline $30 \mathrm{~W}$ & 25 & $15-16$ & $4,475 \mathrm{~S}$ & 4,447 & 28 & --- \\
\hline $31 \mathrm{Sp}$ & $24-25$ & 16 & 4,360 & 4,300 & 60 & --- \\
\hline $32 \mathrm{Sp}$ & 23 & 16 & 4,150 & 4,152 & -2 & --- \\
\hline $33 \mathrm{Sp}$ & 23 & 15 & 4,160 & 4,155 & 5 & --- \\
\hline $34 W$ & 22 & 13 & $4,508 \mathrm{~S}$ & 4,535 & -27 & --- \\
\hline $35 W$ & 20 & 15 & $4,565 \mathrm{~S}$ & 4,531 & 34 & --- \\
\hline $36 \mathrm{~W}$ & 19 & 11 & $4,616 \mathrm{~S}$ & 4,607 & 9 & --- \\
\hline $37 \mathrm{~W}$ & 16 & 17 & $4,514 \mathrm{D}$ & 4,456 & 58 & --- \\
\hline $38 \mathrm{~W}$ & 15 & 19 & $4,505 \mathrm{D}$ & 4,536 & -31 & --- \\
\hline $39 \mathrm{~W}$ & 13 & $19-20$ & $4,153 S$ & 4,167 & -14 & --- \\
\hline $40 \mathrm{~W}$ & 15 & 15 & $4,509 \mathrm{~S}$ & 4,434 & 75 & --- \\
\hline $41 W$ & 14 & 14 & $4,417 \mathrm{~S}$ & 4,408 & 9 & --- \\
\hline $42 W$ & 12 & $19-20$ & $4,065 \mathrm{~S}$ & 4,058 & 7 & --- \\
\hline $43 W$ & 12 & $15-16$ & $4,265 \mathrm{~S}$ & 4,337 & -72 & --- \\
\hline $44 W$ & $11-12$ & 13 & $4,375 \mathrm{~S}$ & 4,378 & -3 & --- \\
\hline $45 \mathrm{Sp}$ & 8 & 13 & 4,440 & 4,485 & -45 & $-\infty$ \\
\hline $46 W$ & 7 & $11-12$ & $4,850 \mathrm{~S}$ & 4,875 & -25 & --- \\
\hline $47 W$ & 6 & $13-14$ & $4,572 \mathrm{E}$ & 4,594 & -22 & --- \\
\hline $48 W$ & $5-6$ & 10 & $5,093 \mathrm{~S}$ & 5,064 & 29 & -- \\
\hline $49 W$ & $4-5$ & 11 & $4,917 \mathrm{~S}$ & 4,880 & 37 & --- \\
\hline
\end{tabular}

${ }^{1}$ Simulated altitude of water levels are the average values of nodes for indicated rows and columns.

water levels have been calculated:

- The average difference is $-0.98 \mathrm{ft}$;

- The standard deviation of the differences is $51 \mathrm{ft}$;

- The correlation coefficient is 0.99 ; and

- The root mean square difference is $51 \mathrm{ft}$.

The average difference of $-0.98 \mathrm{ft}$ indicates a small bias in the simulated heads. Because the variance is very large compared to the square of the average difference, the bias does not contribute much to the root mean 
square difference of heads. The correlation coefficient between measured and simulated water levels is 0.994 . Such a high value of correlation coefficient indicates that the standard deviation of differences is approximately minimized for the level of complexity in the model.

A histogram of calibration residuals is shown in figure 8 . It indicates that the residuals might be normally distributed. The importance of the near normality of the distribution of residuals is that normality indicates that the deviations of the measured water levels from the simulated water levels might be due to measurement error. (Measurement errors are believed to be normally distributed.) Figure 8 indicates that the residual of $-179 \mathrm{ft}$ associated with site 17 and possibly the residual of $114 \mathrm{ft}$ associated with site 28 are outliers. Further evidence that these sites might be outliers is obtained by noting that both measured water levels were reported by drillers (see table 1), and water levels measured just after a well is drilled and developed probably do not represent static conditions. In any case, it would not be a good idea to make large changes in model parameters or greatly increase the complexity of the model to decrease residuals at these sites.

\section{Areas Where Differences Between Measured and Simulated Water Levels Are Greatest}

The two areas of greatest difference between the measured heads and the simulated heads (see table 1) are the area near the southern rim of the swell around site 17 (see fig. 6) and the area near Mt. Holmes and Mt. Ellsworth, including sites $28,27,26$, and 25 .

There is a large decrease in hydraulic head from site number 16 to site 17 that is not matched by the simulation. Other simulations achieved a match (not shown) through the insertion of a zone of smaller hydraulic conductivity (25 percent of surrounding hydraulic conductivity) between the sites. The zone could be associated with the presence of an anticline (fig. 9, column 7, row 20 to row 24 ).

The other area of mismatch (see table 1) west of Mt. Holmes and Mt. Ellsworth near Lake Powell contains igneous intrusives that are assumed to reduce horizontal flow and enhance vertical flow. These intrusives may create a more complicated hydraulic conductivity and recharge distribution than can be defined by a 3-mi by 3-mi grid size (discretization error). Some improvement in agreement between measured and simulated water levels was attained with an asymmetrical recharge pattern around the Henry Mountains. This is discussed in more detail in the next section of this report. More knowledge of the hydrology west of Mt. Holmes and Mt. Ellsworth is needed to improve the simulation.

Both areas of mismatch are near outcrops where nonlinear changes of potentiometric surface and transmissivity are likely because both are changing rapidly there. In areas of nonlinear changes, a possibility exists of significant simulation error (see section entitled "Differences Between Simulated Water Levels Caused by Grid-Size Reduction"). Grid-size error is inherent in all finite-difference models and is reduced by simulating with a finer grid. 


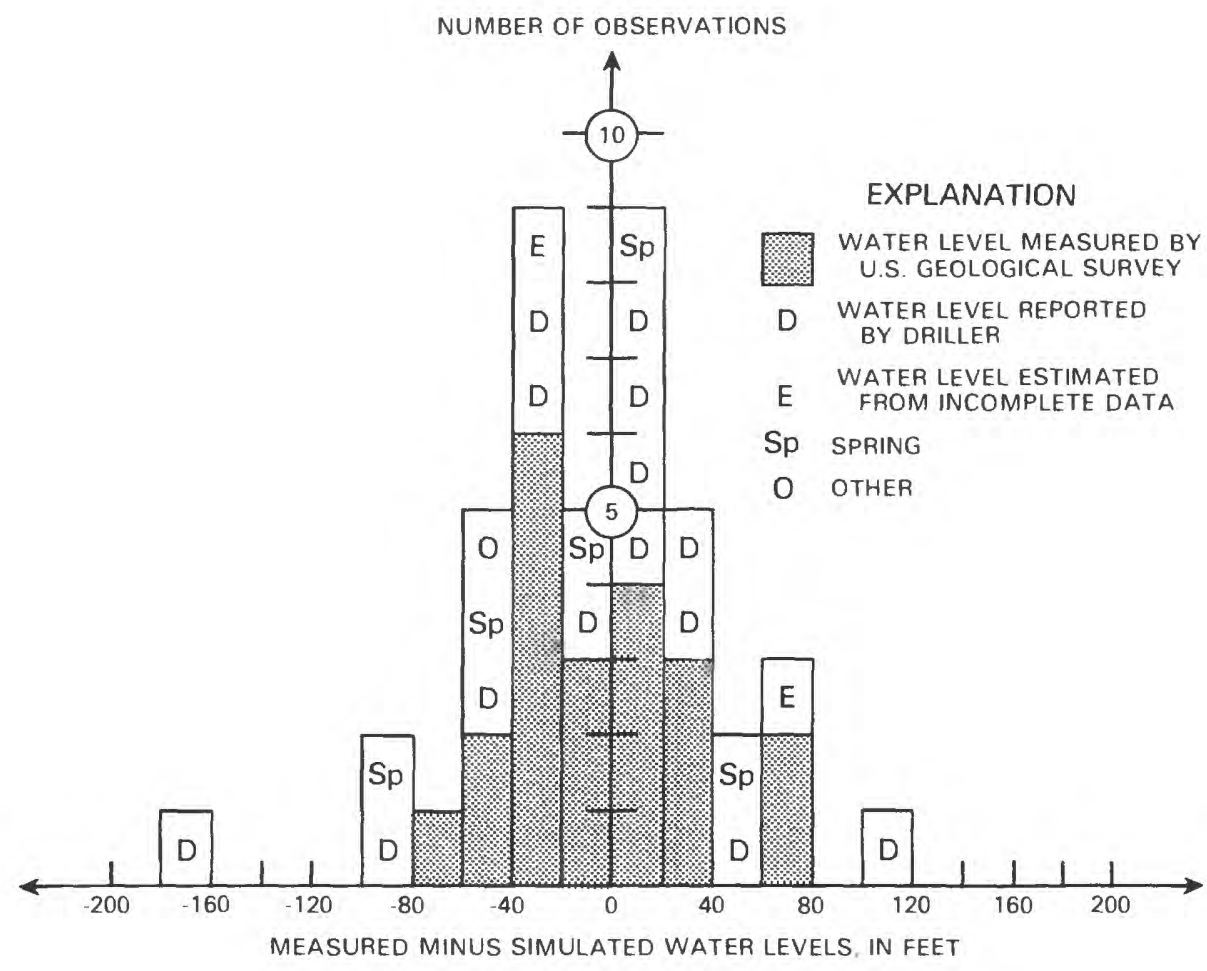

Figure 8.--Histogram of calibration residuals.

Measured heads have errors of measurement associated with them. A common error in water-level measurement in aquifers having a small hydraulic conductivity is making a measurement in a newly drilled well before the water level in the well is in equilibrium with the water in the surrounding aquifer.

Another cause of error is the assumption that all measured water levels are of a static potentiometric surface or are taken at the same time. Actua1ly, the measurements of a changing potentiometric surface were taken at different times. In the Lake Powell area, this error is especially relevant because of the rise of Lake Powell and the resulting rise in aquifer water levels. Water levels in wells $3 \mathrm{mi}$ from the lake have risen more than $40 \mathrm{ft}$ in 15 years.

Lack of data also limits the calibrated model. More data might reveal some changes in the flow pattern presented in this report. Uncertainty due to lack of data is discussed in the following section about sensitivity analysis. 

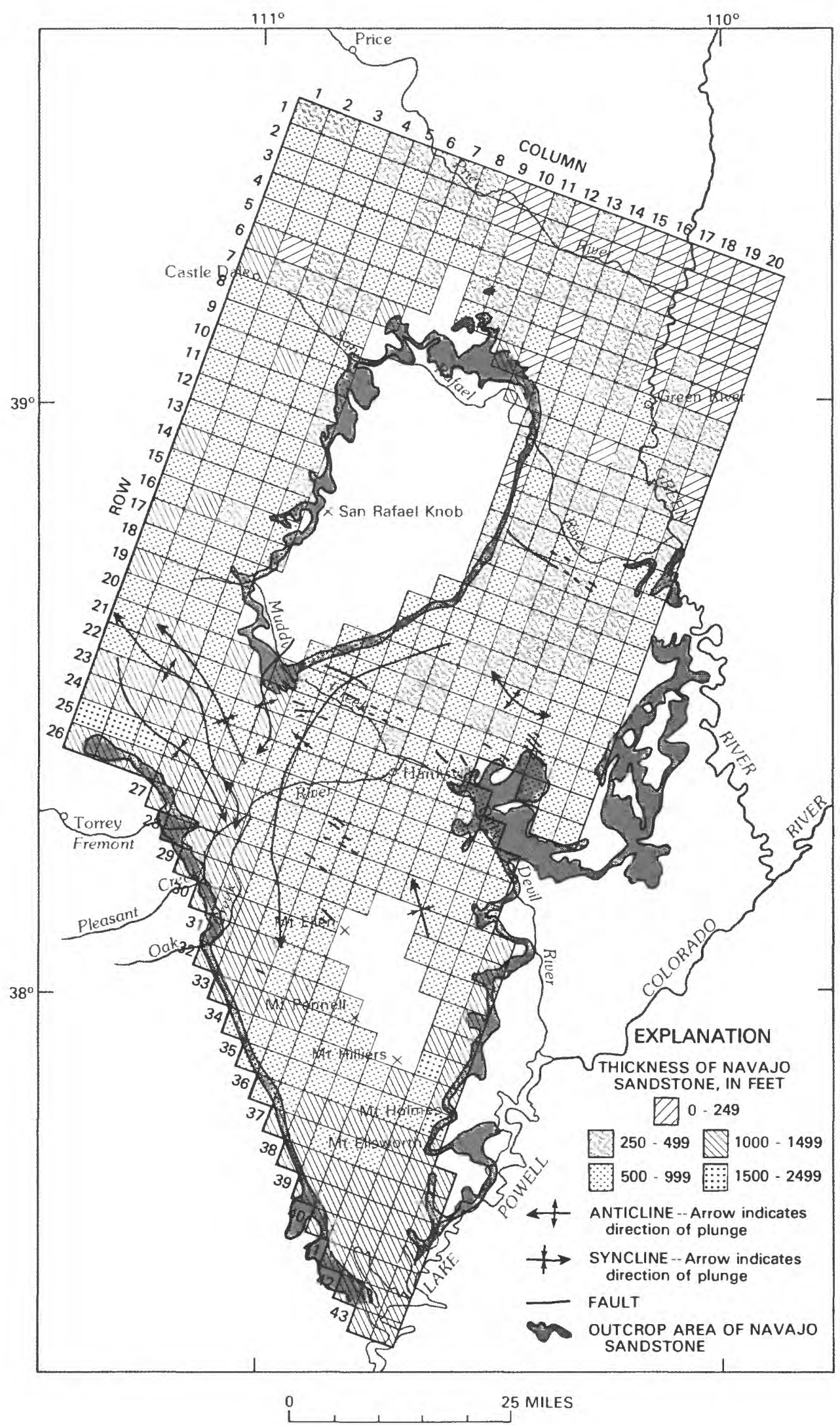

Figure 9.--Thickness of Navajo Sandstone used in model. 


\section{SENSITIVITY ANALYSIS}

Comparing the effects of hydrologic parameter changes on the simulated water levels is called sensitivity analysis. The set of model parameters for the calibrated model defines starting points from which each change is made. These parameters have a range of uncertainty. Variation of a parameter outside its range of uncertainty is not of interest.

One parameter is changed in each simulation and then changed back to its original value for the next simulation. The parameters to which the model is most sensitive are the ones that change the potentiometric surface the most. Once these parameters are identified, additional measurements of the most sensitive parameters can reduce the greatest uncertainty in the model.

\section{Sensitivity to Recharge from Henry Mountains}

In the calibrated model, the well recharge nodes around the Henry Mountains (see fig. 5) each contribute $0.21 \mathrm{ft}^{3} / \mathrm{s}$ of recharge. A simulation that had each node recharging $0.11 \mathrm{ft}^{3} / \mathrm{s}$ resulted in three dry nodes southeast of the Henry Mountains.

Another simulation had recharge of $0.06 \mathrm{ft}^{3} / \mathrm{s}$ in each node around the Henry Mountains, except for two nodes southeast of the Henry Mountains (in row 34 and in columns 16 and 17 ) where recharge was $0.31 \mathrm{ft}^{3} / \mathrm{s}$. Heads matched measured water levels slightly better than the heads of simulations having uniform recharge. As a result of this recharge, heads in nodes 3 to $6 \mathrm{mi}$ distant from the Henry Mountains decreased 50 to $100 \mathrm{ft}$ from calibrated values except near the southeast tip where they were approximately the same or increased slightly. Net recharge around the Henry Mountains decreased from 2.94 to $1.34 \mathrm{ft}^{3} / \mathrm{s}$ by this adjustment. Because recharge around the Henry Mountains is thought to be small compared to the recharge along the Waterpocket fold (Hood, 1980), the smaller rate of recharge might be the preferred estimate; but the asymmetrical recharge pattern has no basis in observation and departs from the simplest model hypothesis.

\section{Sensitivity to Hydraulic-Conductivity Distribution}

A unique hydraulic-conductivity distribution for an aquifer cannot be determined by simulating a known steady-state potentiometric surface. Either hydraulic conductivity or specific discharge also needs to be known on a 
surface that crosses all streamlines (Nelson, 1968; and Frind and Pinder, 1973). In the instance of the Navajo Sandstone, some parts of the potentiometric surface are known, no specific discharges are known, and a few hydraulic-conductivity values have been determined. Aquifer tests were performed using the cluster of wells at site 19 in figure 6; these yielded the the most areally extensive value of hydraulic conductivity of $1.6 \mathrm{ft} / \mathrm{d}$. Values of $0.5 \mathrm{ft} / \mathrm{d}$ were measured from Navajo Sandstone samples taken from the aquifer test wells (Hood and Danielson, 1979). In the aquifer test area a value of $0.7 \mathrm{ft} / \mathrm{d}$ was used in the model because larger values of hydraulic conductivity resulted in simulated heads around site 19 that were too large. The author's modeling experience leads him to assert that the small value of hydraulic conductivity was necessary because the $3-\mathrm{mi}$ by $3-\mathrm{mi}$ grid size was too large to accurately simulate the flow near this outcrop. (See the section titled "Differences Between Simulated Water Levels Caused by Grid-Size Reduction" and, in particular, figure 14.) Seven values of hydraulic conductivity derived from specific-capacity tests having a geometric mean of $2.48 \mathrm{ft} / \mathrm{d}$ and a standard deviation of $21.8 \mathrm{ft} / \mathrm{d}$ are reported in Hood and Danielson (1981). These measurements were taken as a guide for the median value of hydraulic conductivity used in the model. They did not affect the model's distribution of hydraulic conductivity.

The hydraulic-conductivity distribution used in the model and shown in figure 10 has three different ranges. The difference between the smallest and the largest values is a little greater than 100 percent. Near the Navajo outcrop at San Rafael Swell, the hydraulic conductivity increases because of weathering and fracturing. As the Navajo dips away from the swell, hydraulic conductivity is decreased because of overburden pressure (Fatt and Davis, 1952) (see figs. 11 and 3). In the southern half of the model, a uniformly small hydraulic conductivity is sufficient to match the sparser head data there.

Off the southeast rim of the swe1l, from Muddy Creek north and halfway to the San Rafael River, hydraulic conductivity is large. A series of faults runs along the Muddy River from San Rafael Swell to the intersection of the Dirty Devil River and the Navajo Sandstone outcrop (fig. 9). These faults might cause a larger hydraulic conductivity there than elsewhere. They also might cause a local anisotropy in hydraulic conductivity that has not been simulated but might be needed in future simulation studies. Using the hydraulic conductivities shown in figure 10 , an acceptable match to the measured heads was simulated (see table 1).

A good head match also was simulated with a single line of nodes of small hydraulic conductivity (one-fourth of the hydraulic conductivity of the surrounding nodes) along the Henry Mountains syncline. When the line of nodes of small hydraulic conductivity was placed between sites 16 and 17 , more accurate water levels were simulated for those sites. Such a large areally extensive variation in the hydraulic conductivity distribution of a very uniform sandstone such as the Navajo Sandstone best remains only a simulation possibility until supported by additional water-level measurements or aquifer tests. 


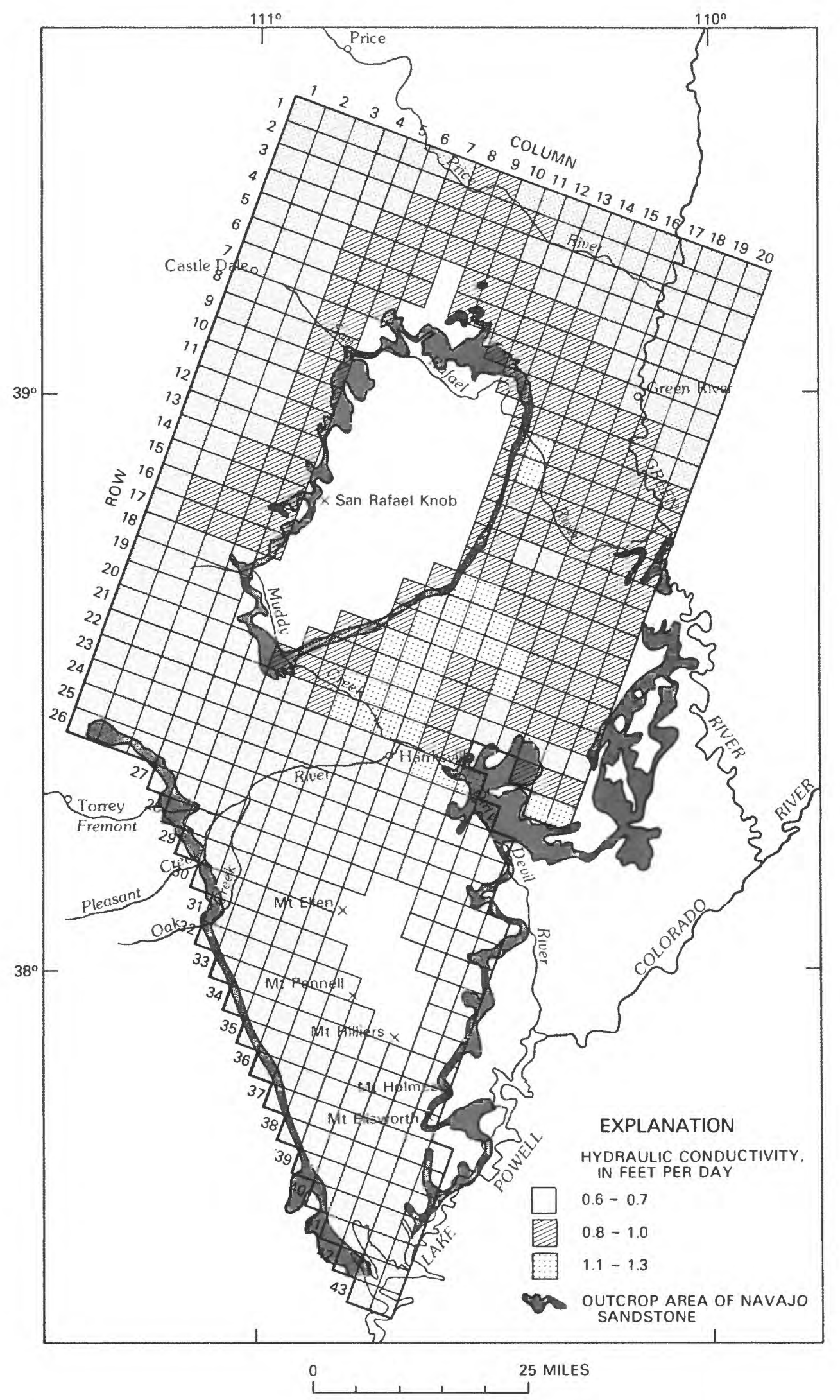

Figure 10.--Distribution of hydraulic conductivity used in model. 


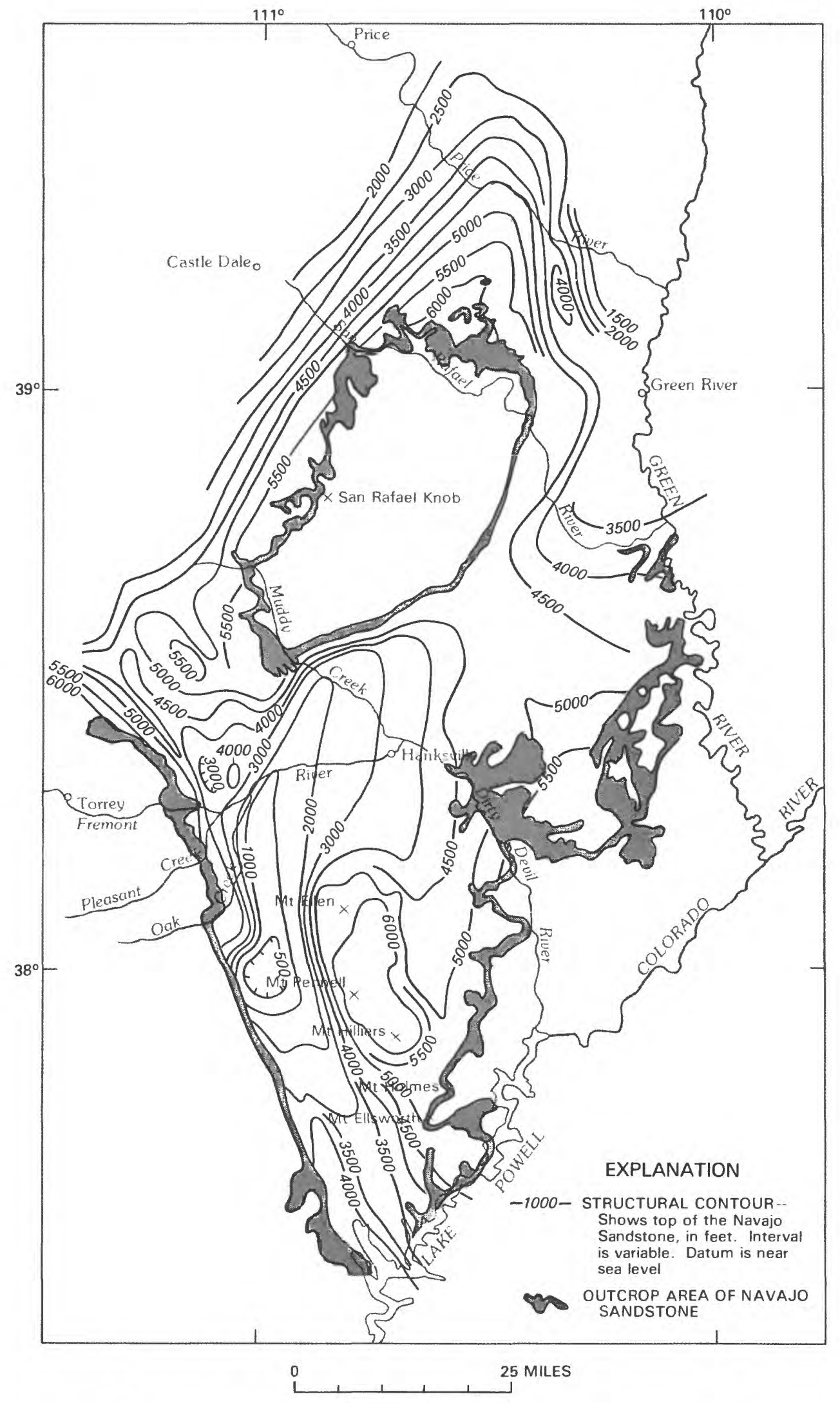

Figure 11.--Structure contours on the top of the Navajo Sandstone. 
A second test of sensitivity to the hydraulic-conductivity distribution was made having hydraulic conductivity equal to $1 \mathrm{ft} / \mathrm{d}$ everywhere. The result was that simulated heads decreased in areas of small hydraulic conductivity, and heads increased in areas of large hydraulic conductivity; an approximate maximum difference from the best simulated potentiometric surface was $50 \mathrm{ft}$.

\section{Sensitivity of Calibration to Changes on Northern Boundaries}

Flow through an aquifer is almost never known, yet simulation necessitates that either the flow through a boundary or hydraulic head at a boundary be specified. For the northern boundaries, hydraulic-head data are not available; therefore, the sensitivity of the model to different heads along these boundaries needs to be checked.

Boundary along row 1: When the external heads of the general head boundary nodes were decreased by $100 \mathrm{ft}$, the heads near the north rim of the swell decreased by $60 \mathrm{ft}$; heads of the west rim were similarly affected; and heads near the east rim decreased 20 to $25 \mathrm{ft}$. In these circumstances, recharge from the north rim of the swell is increased approximately 6 percent from that shown on figure 12 .

Boundary along column 20 to row 9: When the constant heads along this boundary were decreased by $100 \mathrm{ft}$, heads decreased by $30 \mathrm{ft}$ near the northeast rim of the swell and decreased by $50 \mathrm{ft}$ at nodal location row 6 , column 18 . When the boundary was made a no-flow boundary, heads increased by approximately the same amount in the above locations.

Boundary along column 20, row 16 to 21: When the constant heads on this boundary were increased by $100 \mathrm{ft}$, heads increased by $50 \mathrm{ft}$ five nodal columns away from the boundary. When the constant heads on this boundary were decreased by $100 \mathrm{ft}$, many nodes on and near the boundary went dry, and most of the recharge from the boundary stopped.

Boundary along column 1: Many experiments were tried with boundary flow along this boundary. They all indicated that any boundary flow, in or out, that is comparable to other system flows has large effects on the local flow system. The choice of a no-flow boundary is the simplest way to simulate accurately here. Another accurate way to simulate water levels is by a 90-percent reduction of the inflow from the west rim of the swell and a transfer of the deficit inflow to the boundary along column 1. The area between the west boundary and the edge of San Rafael Swell is insensitive to the location of recharge. More measured water levels near the model's west boundary are needed before the location of inflow can be determined.

\section{MAGNITUDES AND DIRECTIONS OF SIMULATED FLOW}

The simulated potentiometric surface is shown in figure 7 , and it is approximately the same as a composite of three subarea potentiometric maps 
(Hood, 1980; Hood and Danielson, 1981; and Hood and Patterson, 1984). The areas of unconfined flow (fig. 7) are consistent with those published for the Dirty Devil basin in Hood and Danielson (1981). The model, using the data of the three previous references, presents a coherent picture of the total ground-water system that is isolated from the surrounding ground-water system except for small subsurface discharge outward along the north and northeast borders of the model (see fig. 12).

A more detailed, quantitative description of the flow system is provided in figure 12, where areal simulated flow is shown through sides of rectangular areas by arrows and numbers near the arrow tips. The direction of the arrow is the approximate direction of flow; the number is the magnitude of flow in $\mathrm{ft}^{3} / \mathrm{s}$. An arrow crosses one side of a rectangle indicating the corresponding flow at the particular segment of the side where it occurs. When more than one arrow crosses a side, the arrow represents flow through the segment it crosses. Thus, a side can have in-pointing arrows as well as out-pointing arrows. Flow through the sides of the rectangles sometimes is supplemented by information on areal recharge, canyon recharge or discharge, and river recharge or discharge. For example, the rectangle having corners at row 30 , column 7 and row 39, column 15, the southwestmost rectangle, has the following budget:

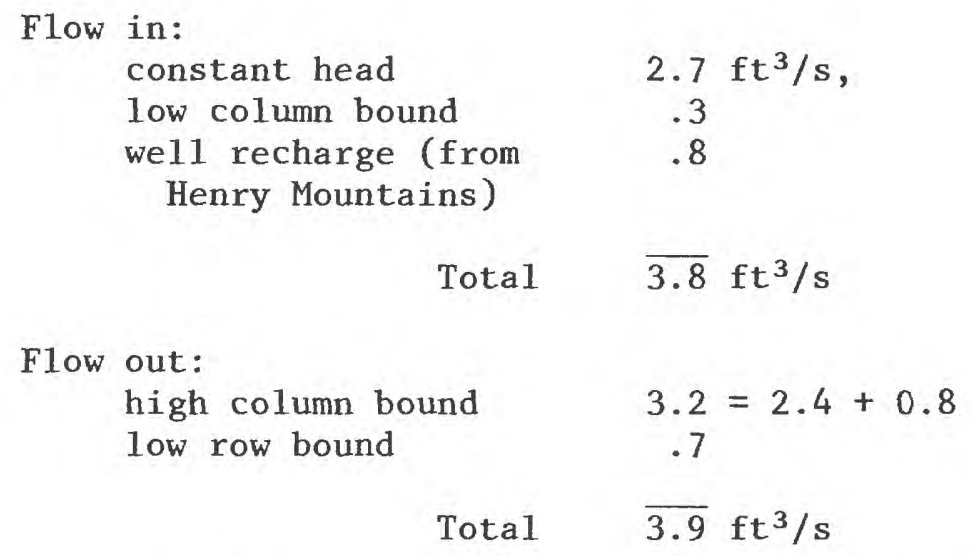

Here, "flow in: constant head" means flow into the area from constant-head nodes, and "flow in: low column bound" means flow in through the boundary formed by nodal cells with the smallest column number of the rectangle, and so forth.

In figure 12 where the San Rafael River enters San Rafael Swell there is the label San Rafael $=-0.4$. Along that canyon, the model simulates a loss from the Navajo of $0.4 \mathrm{ft}^{3} / \mathrm{s}$. There is no distinction made by the model between flow from the Navajo to the river or evaporation or transpiration of ground water along the canyon walls. Thus, no attempt was made to determine the parameters of these different ground-water discharge mechanisms. Instead, the river node's riverbed conductance was adjusted until surrounding measured water levels were matched. 


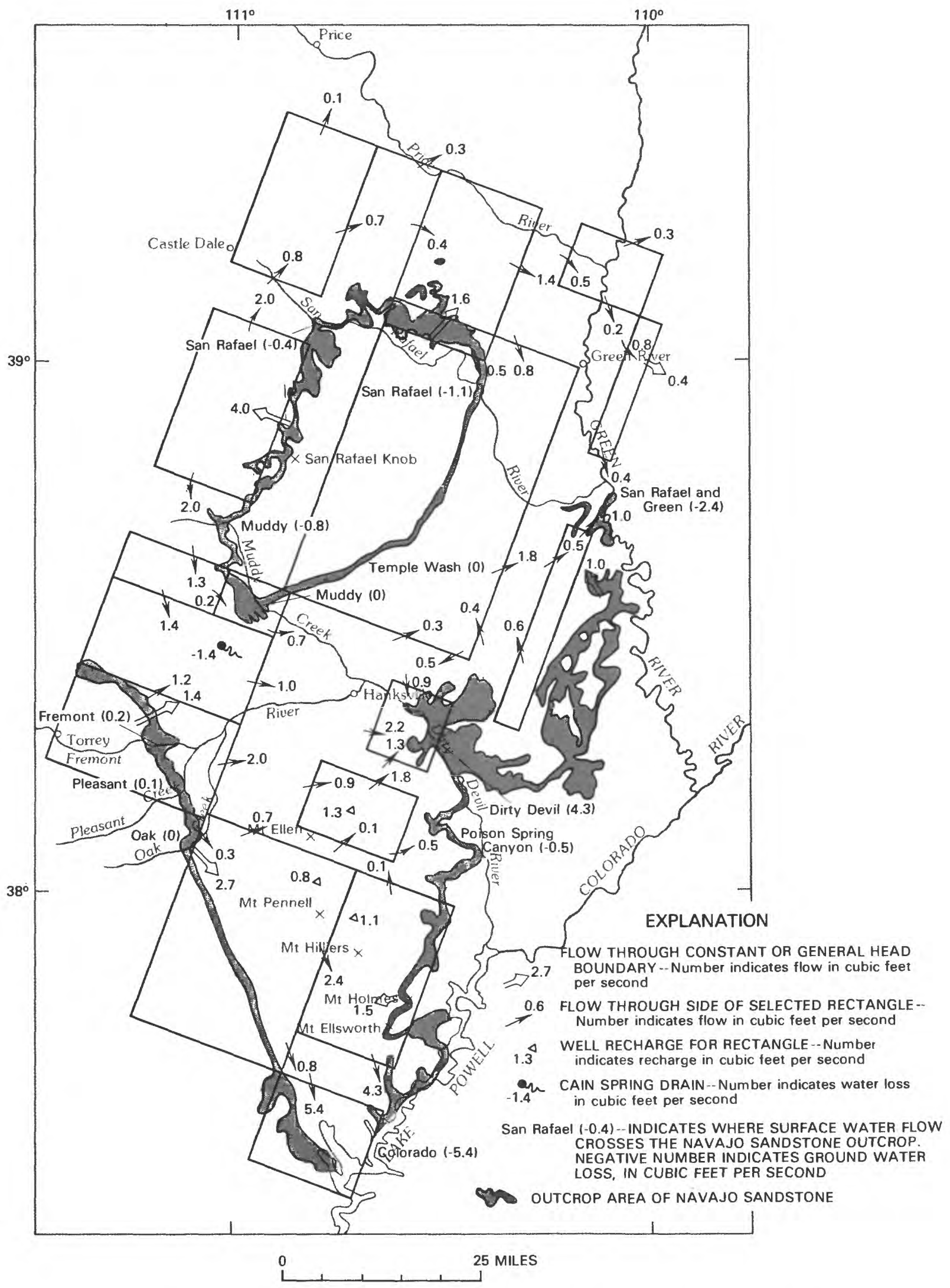

Figure 12.--Simulated flow through sides of selected rectangular areas. 
The estimation of recharge in areas with large Navajo outcrop is based on three factors: the area of the outcrop, yearly precipitation on the outcrop, and the fraction of precipitation that percolates into the ground-water system. The last of these factors is the most uncertain and varies from place to place. Rush and others (1982) give an estimate of 1 percent and supporting data for the northeast part of the modeled area along the Green River north of the Dirty Devil River which has a low precipitation rate (less than 6 in. per year, see fig. 2). In a high precipitation area near the Waterpocket fold, Danielson and Hood (1984) report measurements that show a 14 percent recharge to precipitation ratio. The ratio was reported to vary with outcrop slope and precipitation. High precipitation resulted in a high ratio, but below a certain level of precipitation, zero recharge was found. The modeler found it sufficient and consistent with these results to simulate recharge almost entirely in high precipitation outcrop areas using an appropriately high ratio. A sample calculation for the San Rafael Knob area follows.

Factors:

Outcrop area of four nodal cells, see figure 9.

Area per nodal cell, $9 \mathrm{mi}^{2}$.

Up to $10 \mathrm{in./yr}$ precipitation in area.

Estimated fraction of precipitation entering the system as groundwater recharge, 0.1 .

Estimated recharge $=(4$ nodes $)\left(9 \mathrm{mi}^{2} /\right.$ node $)(10 \mathrm{in} . / \mathrm{yr})(0.1)=3 \mathrm{ft}^{3} / \mathrm{s}$.

This estimate is close to the model recharge in the San Rafael Knob area shown in table 2. Major recharge areas, in order of decreasing recharge and associated estimated recharge, based on the recharge to precipitation ratio of 0.1 are listed in table 2 .

Ground-water flow in North Wash and Trachyte Creek, two other canyons south of Poison Spring Canyon, was not modeled because there are no measured water levels east of the Henry Mountains. North Wash and Trachyte Creek are east of the Henry Mountains, but they are not shown in any figure. Most simulated ground water east of the Henry Mountains discharges into Poison Creek Canyon, but the discharge probably would be better attributed to the three canyons.

As an example of the use of figure 12 in computing the numbers in table 2, consider the recharge from the Waterpocket fold. Adding the numbers associated with arrows crossing the perimeter of rectangles from north to south (Oak Creek), $1.2+2.0+0.3+2.7=6.2$ is obtained. This number is the first recharge recorded in table 2 .

The simulated recharge from the Waterpocket fold area is 100 percent greater than estimated, and approximately 50 percent of the recharge comes from the Oak Creek area. Faults in the Oak Creek area associated with the Teasdale anticline (Hood and Danielson, 1979) probably increase surface and interformational recharge to the Navajo creating the need for the larger recharge of the simulation. 
Table 2.--Simulated and estimated values of major recharge and major simulated discharge

[Recharge and discharge are in cubic feet per second; swell refers to San Rafael Swel1]

\begin{tabular}{|c|c|c|}
\hline $\begin{array}{l}\text { Major model recharge areas in } \\
\text { order of decreasing recharge }\end{array}$ & Model & Estimated \\
\hline Capitol Reef (Waterpocket fold) & 6.2 & 3 \\
\hline 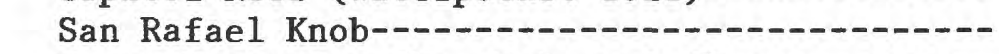 & 4.0 & 3 \\
\hline Henry Mountains (Mt. Holmes 1.5) & 2.9 & 1 \\
\hline Northwest tip of swell & 1.6 & 3 \\
\hline Outcrop area south of the Green River & 1.0 & 4 \\
\hline \multirow[t]{2}{*}{ Southern tip of swell } & .6 & 1 \\
\hline & $\overline{16.3}$ & $\overline{15}$ \\
\hline \multicolumn{3}{|l|}{$\begin{array}{l}\text { Major model discharge areas in order of } \\
\text { decreasing discharge: }\end{array}$} \\
\hline Colorado River- & -5.4 & \\
\hline Dirty Devil River- & -4.3 & \\
\hline \multirow{2}{*}{\multicolumn{3}{|c|}{ Confluence of the San Rafael and the Green }} \\
\hline & & \\
\hline Caine Spring- & -1.3 & \\
\hline San Rafael River (out of swell) & -1.1 & \\
\hline Muddy River (into swell) & -0.8 & \\
\hline Through at northeast corner of swell & -0.7 & \\
\hline Poison Spring Canyon- & -0.5 & \\
\hline \multirow{2}{*}{ San Rafael River (into swell) } & -0.4 & \\
\hline & $-\overline{16.9}$ & \\
\hline
\end{tabular}

Simulated recharge of $4 \mathrm{ft}^{3} / \mathrm{s}$ enters the Navajo outcrop on the west side of San Rafael Swell and splits into two equal parts (see fig. 12). One part flows north. After a loss through the north model boundary and after a loss through the canyon walls where the San Rafael River enters San Rafael Swell, a flow of $0.4 \mathrm{ft}^{3} / \mathrm{s}$ remains. The $0.4 \mathrm{ft}^{3} / \mathrm{s}$ flow moves around the northern tip of San Rafael Swell and increases to $1.9 \mathrm{ft}^{3} / \mathrm{s}\left(1.4 \mathrm{ft}^{3} / \mathrm{s}\right.$ out the opposite side and $0.5 \mathrm{ft}^{3} / \mathrm{s}$ out the bottom of the top center rectangle in $\mathrm{fig}$. 12) after flowing around the area of recharge at the northeast tip of San Rafael Swell. As the $1.9 \mathrm{ft}^{3} / \mathrm{s}$ of flow moves past the northeast tip of the swell, approximately $0.5 \mathrm{ft}^{3} / \mathrm{s}$ (the $0.5 \mathrm{ft}^{3} / \mathrm{s}$ out the bottom of the top center rectangle in fig. 12) of the flow is within $3 \mathrm{mi}$ of the San Rafael Swell outcrop. All the $1.9 \mathrm{ft}^{3} / \mathrm{s}$ of flow leaves the modeled area at the confluence of the San Rafael and the Green Rivers and at the model's boundaries north of the confluence. No addition to flow is made from the east rim of San Rafael Swell. 
The second part of the recharge from San Rafael Knob flows south and discharges $0.8 \mathrm{ft}^{3} / \mathrm{s}$ into Muddy River Canyon (shown in fig. 12 as Muddy $(-0.8))$. Caine Spring accounts for a loss of $1.4 \mathrm{ft}^{3} / \mathrm{s}$, and recharge from the southernmost tip of San Rafael Swell adds $0.6 \mathrm{ft}^{3} / \mathrm{s}$. As this flow moves around the southern tip of San Rafael Swell, approximately $3.2 \mathrm{ft}^{3} / \mathrm{s}(1.2$ $\mathrm{ft}^{3} / \mathrm{s}$ out the top and $2.0 \mathrm{ft} 3 / \mathrm{s}$ out the side of the leftmost rectangle) is added to it by recharge from Waterpocket fold outcrop. Most of the resultant flow discharges into Dirty Devil Canyon. Only $0.8 \mathrm{ft}^{3} / \mathrm{s}$ flows past the canyon toward the east side of San Rafael Swell.

Another major area of recharge from precipitation is the Navajo Sandstone outcrop in the Waterpocket fold area. Approximately one-half $\left(3.0 \mathrm{ft}^{3} / \mathrm{s}\right)$ of the ground-water recharge entering the Navajo there flows south. The southflowing recharge comes from the southern Waterpocket fold area between Pleasant and Oak Creeks. Eventually this recharge discharges along the Colorado River, in column 20, rows 39-43 on the model grid (see fig. 5). A like amount of recharge originates in the Henry Mountains and discharges along the Colorado River.

Although the simulation was a reasonable match to water-level data throughout the modeled area, the same match could have been achieved for any multiple of the flow rates discussed above, using an appropriate change in hydraulic conductivity. Matching a potentiometric surface does not yield a unique areal distribution of flow. From the range of measured values of hydraulic conductivity, the uncertainty in quantity of flow is estimated to be from three times the simulated distribution to one-third the simulated distribution. This uncertainty is consistent with the uncertainty in the known recharge which is considerably larger.

\section{DIFFERENCES BETWEEN SIMULATED WATER LEVELS CAUSED BY GRID-SIZE REDUCTION}

The basis of ground-water flow calculations is the ground-water flow equation and its associated boundary conditions. For field problems, exact solutions of the ground-water flow equation cannot be attained; the best that can be done are approximate solutions. Because a comparison between an approximate solution and the exact solution cannot be made, the goodness of the approximate solution can never be evaluated. For the finite-difference method of approximation, the only well-known guide of solution goodness is: As the finite difference or grid size gets smaller, the approximate solutions approach the exact solution. Estimating the accuracy of the finite-difference solution by decreasing the grid size is described below. 
To solve the partial differential equation of ground-water flow by the finite-difference method, the terms of the equation containing partial differentiation are set equal to algebraic expressions; this is called the finite differencing of the flow equation (MacDonald and Harbaugh, 1984). Finite differencing usually gives rise to errors called discretization error and truncation error. Truncation error occurs because terms like $\left(\frac{\partial^{2} h}{\partial x^{2}}\right)_{i}$ that

occur in the ground-water flow equation are approximated by algebraic expressions like:

$$
\begin{gathered}
\left(h_{i+1}-2 h_{i}+h_{i-1}\right) / \Delta x_{i}^{2}, \quad \text { when actually } \\
\frac{h_{i+1}-2 h_{i}+h_{i-1}}{\Delta x_{i}^{2}}=\left(\frac{\partial^{2} h}{\partial x^{2}}\right)_{i}+\frac{1}{12}\left(\frac{\partial^{4} h}{\partial x^{4}}\right)_{i} \Delta x_{i}^{2}+\ldots
\end{gathered}
$$

Here $\quad h$ is hydraulic head, $\mathrm{x}$ is linear distance along the $\mathrm{x}$-axis, and $\Delta \mathrm{x}$ is the length of a nodal cell.

The subscripts $i, i-1$, and $i+1$ refer to the $i$ th node, the $i-1$ node, and the $i+1$ node. Thus, $x_{i}$ is the $x$-coordinate of the ith node, $h_{i}$ is the hydraulic head at the ith node, and so forth. The above equation is only true when $\Delta x_{i+1}=\Delta x_{i}=\Delta x_{i-1}$. To make the approximation, the infinite series on the right-hand ${ }^{i}$ side of ${ }^{1}$ the above equation is truncated; all terms but the first are ignored. The truncation error is proportional to $\Delta x_{i}^{2}$; thus, the approximation is known as being "second-order accurate in $\Delta x_{i} . "$ ' As $\Delta x_{i}$ is made smaller, the error due to truncation is decreased. The approximation of the differential operation is a source of error in the numerical solution of the flow equation for all but the simplest problems that have solutions such as constants and linear functions.

Finite differencing also results in approximations to the areal distribution of parameters, the boundaries, and boundary conditions of the flow problem. Curved boundaries are approximated by a series of rectangular or square nodal cells, and continuous boundary values are approximated by discontinuous point values. Thus, the finite-difference problem is different than the original boundary-value problem. The differences resulting from these approximations are called discretization errors. As more and more nodal cells are assigned to a given area and as the values assigned to each nodal cell approximate the continuum of values of the boundary value problem, the discretization error approaches zero. As the truncation error and discretization error approach zero, the finite difference solution approaches the solution to the boundary value problem. For a general discussion of truncation and discretization errors, see Aziz and Settari (1979). 
The area chosen for grid-size reduction is the northeast corner of the modeled area, rows 1 to 9 and columns 8 to 20 (fig. 13). This area has steeply dipping beds in which water-table and artesian conditions exist. The curved potentiometric surface and nonlinear changes in transmissivity characterize an area of potentially large truncation error.

Each original nodal cell of the model was divided into nine equal nodal cells. For an example, see the upper right-hand node of figure 13. All other parameters were kept the same except along column 8 and row 9 where constant heads equal to those of the calibrated potentiometric surface were specified. Specified constant heads are necessary because only a part of the whole study area was simulated. In the model using 1-mi by 1-mi nodal cells, specified constant heads are in the center of the following nodal cells in figure 13: column 8 , rows 2,3 , and 4 , and in row 9 , columns $14,15,16,17$, 18 and 19. At the center of each of these nodal cells, a hydraulic head was simulated using the coarse grid; that simulated head is specified as a constant head for the fine-grid simulation. An estimate of error is the difference between the calibrated heads in figure 7 and the heads simulated using the fine grid. Because of the presence of specified constant heads, any error simulated for the northeast part of the modeled area is only an estimate of the error that would occur if the whole study area were simulated with the fine grid.

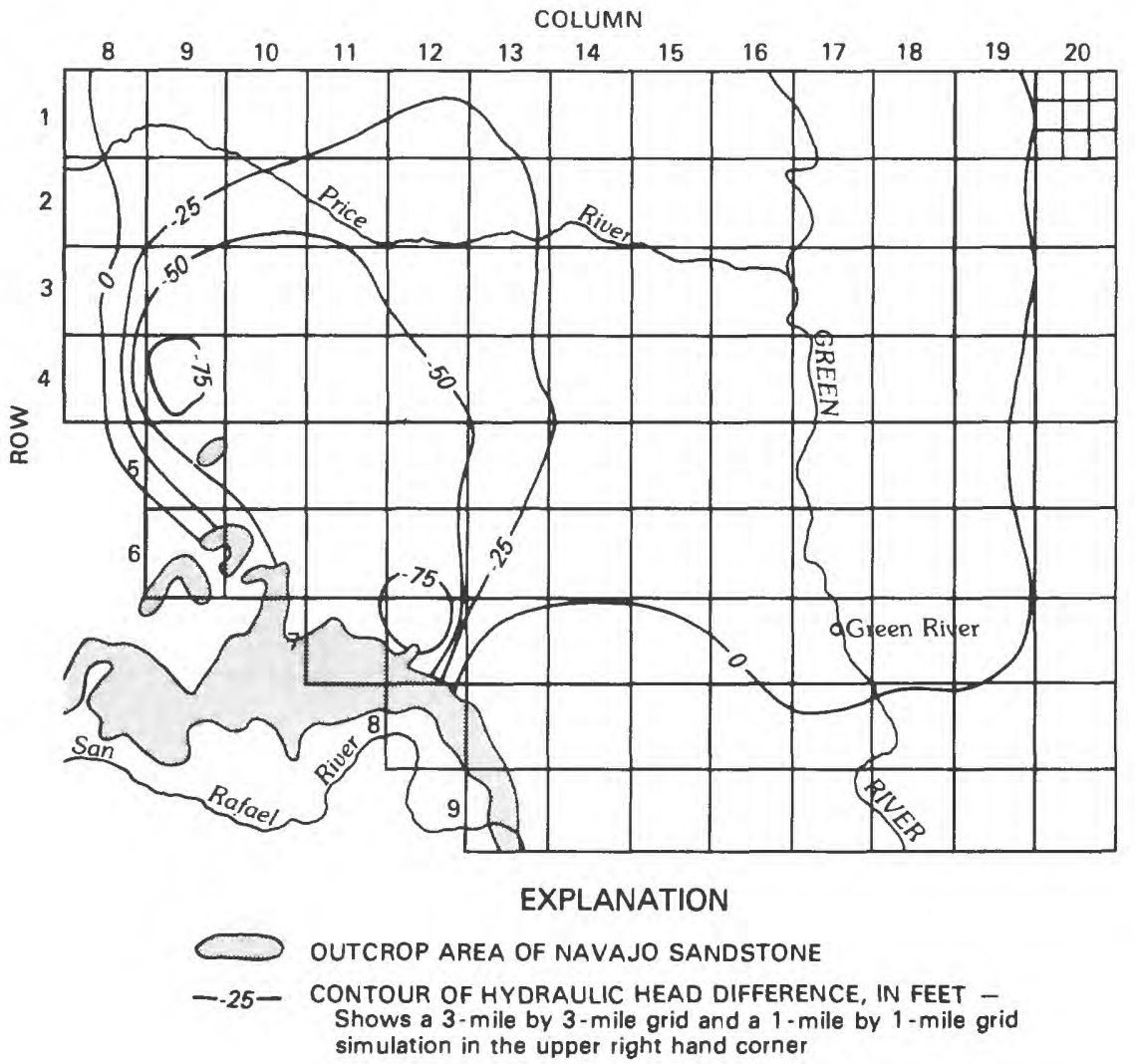

Figure 13.--Differences in simulated water-levels caused by grid-size reduction in the northeast corner of model grid. 
In the first simulation, 32 nodes went dry along the San Rafael Swell rim, blocking recharge from the rim and indicating a difference in the simulated flow system due only to the fine grid. No further comparisons using the first simulation were made.

To avoid dry nodes and to make estimates of the truncation error, two changes were tried. The first change was to define the bottom and top of the Navajo aquifer more accurately in the area of the dry nodes of the first simulation. This was done by changing the top and bottom elevations for the eight additional nodes near the outcrop thereby reducing discretization error. A simulation incorporating new top and bottom elevations resulted in 10 nodes going dry along the San Rafael Swell rim. Some of these nodes were the vital head-dependent boundary nodes that simulated recharge into the outcrop.

Injection of the recharge blocked by the dry nodes at other nodes toward the model interior was tried. For the dry head-dependent boundary nodes, a recharge rate was calculated using the coarse-grid simulated heads, the coarse-grid external input heads, and the input conductances of the calibrated coarse-grid simulation. The equation used in this calculation was:

$$
Q=C\left(h-h_{s}\right)
$$

where

$Q$ is the flow into the node $\mathrm{L}^{3} / \mathrm{T}$,

$C$ is the conductance of head dependent node $L^{2} / T$,

$h$ is the external input head, and

$\mathrm{h}_{\mathrm{s}}$ is the head from the calibrated coarse-grid simulation.

In a final fine-grid simulation, these calculated flows were injected using well recharge nodes, and the recharge entered the model. Simulated heads off the outcrop were 60 to $90 \mathrm{ft}$ less than heads off the outcrop for the calibrated coarse-grid simulation (fig. 14).

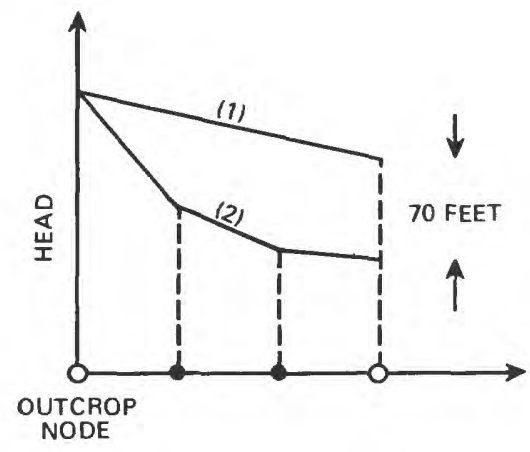

EXPLANATION

O NODE OF 3-MILE BY 3-MILE GRID AND NODE OF 1-MILE BY 1-MILE GRID

- NODE OF 1 - MILE BY 1-MILE GRID

(1) SIMULATED WATER LEVEL WITH 3 - MILE BY 3 - MILE GRID

(2) SIMULATED WATER LEVEL WITH 1 - MILE BY 1 - MILE GRID

Figure 14.--Typical changes in simulated water levels caused by grid-size reduction near the San Rafael Swell. 
Heads for the fine-grid simulation can be increased to the heads of the calibrated coarse-grid simulation by increasing recharge near the San Rafael Swell outcrop by 50 to 75 percent. Thus, as a crude compensation for gridsize error, a 50-percent increase in outcrop recharge and boundary outflow can be associated with the heads and hydraulic-conductivity distribution of the calibrated coarse-grid simulation. The underestimate of recharge at the Navajo outcrop on San Rafael Swell by the coarse-grid simulation is well within the limits of uncertainty in knowledge about recharge (see section entitled "Magnitudes and Directions of Simulated Flow").

Hydraulic heads simulated for the same point using the fine-grid and the coarse-grid are compared in table 3 . The magnitude of this difference is an estimate of the truncation error and discretization error inherent in the simulation with the coarse grid. (The difference is only an estimate, because there might be a significant error in the simulation using the fine grid. This has not been investigated.)

Some statistical characteristics of the head differences between the coarse-grid and fine-grid simulations have been calculated. For the subset of data close to the outcrop and far from the constant head boundary, columns 9 to 13 in figure 13:

- The average difference is $-45 \mathrm{ft}$;

- The variance of these differences is $752 \mathrm{ft}^{2}$; and

- The root mean square head difference is $53 \mathrm{ft}$.

Here bias is a major part of the root mean square head difference. The root mean square head difference (between the coarse-grid and fine-grid simulations) is approximately equal to the root mean square of the difference between the measured heads and the simulated heads using the coarse grid (see section titled "Statistical Evaluation of Errors") indicating that more accurate calibration using the coarse grid is of no value.

For the subset of data from columns 9 to 17 :

- The average difference is $-16 \mathrm{ft}$;

- The variance of these differences is $758 \mathrm{ft}^{2}$; and

- The root mean square head difference is $37 \mathrm{ft}$.

Because the subset of data from columns 9 to 17 includes more of the heads that are near the constant head boundaries, the root mean square head difference decreases.

\section{FLOW DUE TO DENSITY DIFFERENCES}

One of the assumptions of the simulation software (MacDonald and Harbaugh, 1984) is that ground water has a constant density. Strictly speaking, in a natural system this never is true. Dissolved solids in the ground water, temperature differences, and pressure differences from one aquifer element to another create density differences. The ground water that is more dense tends to flow downdip, and the ground water that is less 
Table 3.--A comparison between hydraulic heads simulated using a fine and a coarse model grid for the northeast corner of the modeled area

[Each new column number starts at row 2 and increases downward in the table, see figure 13]

\begin{tabular}{|c|c|c|c|}
\hline $\begin{array}{l}\text { Column } \\
\text { number }\end{array}$ & $\begin{array}{l}\text { Head in feet, } \\
\text { using a } \\
\text { 1-mile by } 1-\text { mile } \\
\text { grid }\end{array}$ & $\begin{array}{l}\text { Head in feet, } \\
\text { using a } \\
\text { 3-mile by } 3-\text { mile } \\
\text { grid }\end{array}$ & Difference in head \\
\hline 9 & 4,985 & 5,010 & -25 \\
\hline 9 & 4,957 & 5,005 & -48 \\
\hline 9 & 4,902 & 4,994 & -92 \\
\hline 10 & 4,882 & 4,915 & -33 \\
\hline 10 & 4,861 & 4,912 & -51 \\
\hline 10 & 4,831 & 4,897 & -66 \\
\hline 10 & 4,802 & 4,863 & -61 \\
\hline 11 & 4,796 & 4,831 & -35 \\
\hline 11 & 4,780 & 4,827 & -47 \\
\hline 11 & 4,759 & 4,818 & -59 \\
\hline 11 & 4,738 & 4,802 & -64 \\
\hline 11 & 4,737 & 4,810 & -73 \\
\hline 12 & 4,720 & 4,755 & -35 \\
\hline 12 & 4,709 & 4,750 & -41 \\
\hline 12 & 4,692 & 4,742 & -50 \\
\hline 12 & 4,669 & 4,728 & -59 \\
\hline 12 & 4,643 & 4,718 & -75 \\
\hline 12 & 4,603 & 4,699 & -98 \\
\hline 13 & 4,639 & 4,671 & -32 \\
\hline 13 & 4,626 & 4,662 & -36 \\
\hline 13 & 4,607 & 4,644 & -37 \\
\hline 13 & 4,571 & 4,598 & -27 \\
\hline 13 & 4,524 & 4,509 & 15 \\
\hline 13 & 4,491 & 4,469 & 22 \\
\hline 14 & 4,579 & 4,601 & -22 \\
\hline 14 & 4,573 & 4,597 & -24 \\
\hline 14 & 4,561 & 4,584 & -23 \\
\hline 14 & 4,542 & 4,562 & -20 \\
\hline 14 & 4,513 & 4,522 & -9 \\
\hline 14 & 4,485 & 4,479 & 6 \\
\hline 14 & 4,458 & 4,445 & 13 \\
\hline 15 & 4,525 & 4,541 & -16 \\
\hline 15 & 4,523 & 4,540 & -17 \\
\hline 15 & 4,512 & 4,529 & -17 \\
\hline 15 & 4,493 & 4,507 & -14 \\
\hline 15 & 4,467 & 4,473 & -6 \\
\hline
\end{tabular}


Table 3.--A comparison between hydraulic heads simulated using a fine and a coarse model grid for the northeast corner of the modeled area--Continued

\begin{tabular}{|c|c|c|c|}
\hline $\begin{array}{l}\text { Column } \\
\text { number }\end{array}$ & $\begin{array}{l}\text { Head in feet, } \\
\text { using a } \\
\text { 1-mile by } 1-\text { mile } \\
\text { grid }\end{array}$ & $\begin{array}{l}\text { Head in feet, } \\
\text { using a } \\
\text { 3-mile by } 3-\text { mile } \\
\text { grid }\end{array}$ & Difference in head \\
\hline 15 & 4,441 & 4,439 & 2 \\
\hline 15 & 4,418 & 4,412 & 6 \\
\hline 16 & 4,470 & 4,479 & -9 \\
\hline 16 & 4,476 & 4,487 & -11 \\
\hline 16 & 4,470 & 4,480 & -10 \\
\hline 16 & 4,454 & 4,463 & -9 \\
\hline 16 & 4,429 & 4,436 & -7 \\
\hline 16 & 4,399 & 4,440 & -41 \\
\hline 16 & 4,380 & 4,380 & 0 \\
\hline 17 & 4,421 & 4,426 & -5 \\
\hline 17 & 4,432 & 4,439 & -7 \\
\hline 17 & 4,429 & 4,436 & -7 \\
\hline 17 & 4,417 & 4,423 & -6 \\
\hline 17 & 4,388 & 4,392 & -4 \\
\hline 17 & 4,359 & 4,358 & 1 \\
\hline 17 & 4,338 & 4,338 & 0 \\
\hline
\end{tabular}

dense tends to flow updip. Flow is not solely due to head differences. If density-induced flow were important, then a serious error would be made in using a model that does not account for it. The purpose of this section is to determine if ground-water flow due to density differences is important in in the modeled area. An area where the greatest measured dissolved solids occur is examined. Temperature and pressure differences from standard laboratory conditions are ignored. They are, in most instances, secondary considerations in determining density of ground water (Potter and Brown, 1977).

In Middle Desert, at site 14 in figure 6, a sample of ground water from the Navajo Sandstone was analyzed as having $70,800 \mathrm{mg} / \mathrm{L}$ (milligrams per liter) sodium chloride (Hood and Danielson, 1979). The sample had a specific gravity of 1.05 . To calculate the specific discharge due to the density difference from pure water, it is necessary to consider Darcy's law for a variable density liquid (Scheidegger, 1974):

$$
\vec{q}=-\frac{k}{\mu}(\nabla p-\overrightarrow{\rho g})
$$

where

$$
\begin{aligned}
& \vec{q} \text { is specific discharge, } L / T, \\
& \mathrm{k} \text { is the permeability, }{ }^{2}, \\
& \mu \text { is the viscosity, M/LT, } \\
& \mathrm{p} \text { is the pressure, M/LT }, \\
& \rho \text { is the density, M/L } 3 \text {, and } \\
& \overrightarrow{\mathrm{g}} \text { is the acceleration of gravity, } L / \mathrm{T}^{2} \text {. }
\end{aligned}
$$


This can be rewritten in terms of pure-water head, $h$, as:

$$
\vec{q}=-\frac{\rho_{0}}{\rho} K\left(\nabla h+\frac{\Delta \rho}{\rho_{0}} \hat{k}\right)
$$

where

$$
\begin{aligned}
& K \text { is hydraulic conductivity, L/T, } \\
& h \text { is } p / \rho_{0} g+z, L, \\
& \Delta \rho \text { is } \rho-\rho_{0}, M^{3} / L, \\
& \rho_{O} \text { is pure-water density, } 62.4 \mathrm{lb} / \mathrm{ft}^{3}, \mathrm{M}^{3} / \mathrm{L}, \\
& \hat{K} \text { is a unit vector pointing upward, and } \\
& z \text { is the elevation at which head is measured, } L \text {. }
\end{aligned}
$$

In the previous equation, the two driving forces, the pure-water-head gradient and density difference, are separated. The component of specific discharge moving up a slope that makes an angle " $a$ " with the horizontal, is:

$$
q_{a}=-\frac{\rho_{0}}{\rho} K\left(-|\nabla h|+\frac{\Delta \rho}{\rho_{0}} \sin a\right) .
$$

Here Th is assumed along the slope and pointing downslope. This is the case in the following example.

At the Middle Desert well, the Navajo dips northwestward and the purewater head decreases toward the east (Hood and Danielson, 1979). The question arises, is the pure-water-head gradient driving brine updip large enough to overcome the force of gravity pulling the brine downdip? The freshwater-head difference on the $10-\mathrm{mi}$ slope is $350 \mathrm{ft}$, and the altitude difference is 1,750 $\mathrm{ft}$. These data are based on extrapolations and interpolations found in Hood and Danielson (1979). The ratio of specific discharge caused by head gradient to the specific discharge caused by density difference is:

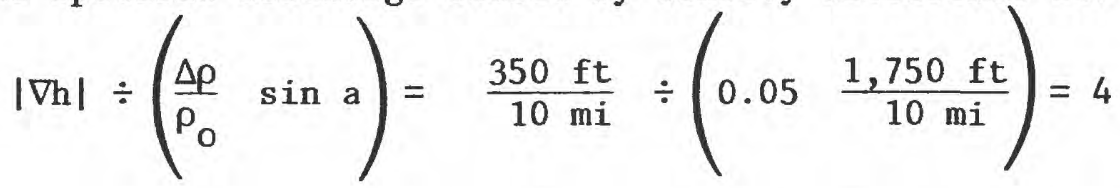

Thus, gravity forces decrease the updip flow due to the pure-water-head gradient by one-quarter in this region. 
Other water samples taken from the Navajo Sandstone in the modeled area contained less than $5,000 \mathrm{mg} / \mathrm{L}$ of dissolved solids, and most samples contained considerably less than $5,000 \mathrm{mg} / \mathrm{L}$. From the sparse data that characterize the modeled area, it seems reasonable to ignore density effects on regional flow patterns in the coarse-grid model. However, if a finer-grid model of the Middle Desert area were constructed from additional data that decreased the uncertainty of the flow system to less than 25 percent, then density differences would have to be considered.

\section{SUMMARY AND CONCLUSIONS}

A two-dimensional, finite-difference ground-water flow model of the Navajo Sandstone was constructed to match the hydraulic head data in southeast Utah. The simulated flow pattern was illustrated as a potentiometric surface and as flow rates into and out of selected areas. The sparse data distribution allowed the simplest hypotheses about the ground-water system. A uniform hydraulic conductivity distribution of $0.7 \mathrm{ft} / \mathrm{d}$ was used in the southern half of the modeled area for the simulation.

All values of hydrologic parameters used were consistent with measured values and their uncertainties. The hydraulic conductivity for the calibrated simulation approximated the measured values in the model area and ranged from $0.6 \mathrm{ft} / \mathrm{d}$ to $1.3 \mathrm{ft} / \mathrm{d}$. Simulated recharge for the major recharge areas approximated estimated recharge.

The estimated grid-size error for the model was surprisingly large considering the small nodal cell selected. The model used 3-mi by 3-mi nodal cells. To estimate grid-size error, a subarea was simulated with a model having 1 -mi by 1 -mi nodal cells. In the Navajo outcrop area on San Rafael Swe11, the heads simulated using the fine-grid model were as much as $90 \mathrm{ft}$ less than the heads simulated using the coarse-grid model. Recharge 50 percent greater than that of the coarse-grid model was required near the outcrop by the fine-grid model to simulate nearly the same potentiometric surface near the outcrop. The 50-percent increase in recharge at San Rafael Swell is well within the range of uncertainty.

To find the most sensitive model parameters, tests were made. Sensitivity to hydraulic-conductivity distribution, boundary conditions, and recharge were significant when these were varied within their ranges of uncertainty. The model was most sensitive to the location and strength of some recharge areas because quantity and location of recharge have large uncertainty. However, the model was shown to be insensitive to an interchange of a major recharge area and a no-flow boundary west of San Rafael Swell.

Ground water 5 percent heavier than surrounding water exists in an area $5 \mathrm{mi}$ north of Waterpocket fold. In this area, simulated flow rates are 33 percent greater than flow rates calculated assuming variable-density ground water. This error is less than that caused by grid-size error, lack of data, 
and uncertainty in data at that location. Presently (1984), available data indicate that no other area has nearly as great a density difference; consequently, the omission of density considerations is justified.

In the Colorado River Basin aquifer system, forces due to head gradients, density differences, dissolved-solids gradients, electric field gradients, and temperature gradients move water. To accurately determine quantity and direction of flow in areas where head gradients are sma11, other forces need to be considered. However, because head gradients are large, the flow of most of the water is attributable to head gradients. 


\section{REFERENCES}

Aziz, Khalid, and Settari, Antonín, 1979, Petroleum reservoir simulation: London, Applied Science Publishers, Ltd., ch. 3.

Danielson, T.W., and Hood, J.W., 1984, Infiltration to the Navajo Sandstone in the lower Dirty Devel River basin, Utah, with emphasis on techniques used in its determination: U.S. Geological Survey Water-Resources Investigations Report 84-4154, $45 \mathrm{p}$.

Fatt, Irving, and Davis, D.H., 1952, Reduction in permeability with overburden pressure, in Transactions of the American Institute of Mining and Metallurgical Engineers, Technical Note 147, v. 195, p. 329.

Frind, E.0., and Pinder, G.F., 1973, Galerkin solution of the inverse problem for aquifer transmissivity: Water Resources Research, v. 9, no. 5, p. 1397-1410.

Hood, J.W., and Danielson, T.W., 1979, Aquifer tests of the Navajo Sandstone near Caineville, Wayne County, Utah: Salt Lake City, Utah Department of Natural Resources and Energy, Technical Publication No. 66, 69 p.

Hood, J.W., 1980, The Navajo Sandstone: A regional aquifer in Henry Mountains Symposium: Salt Lake City, Utah Geological Association, p. 267-275.

Hood, J.W., and Danielson, T.W., 1981, Bedrock aquifers in the lower Dirty Devil River basin area, Utah, with special emphasis on the Navajo Sandstone: Utah Department of Natural Resources and Energy, Technical Publication No. 68, 143 p.

Hood, J.W., and Patterson, D.J., 1984, Bedrock aquifers in the northern San Rafael Swell area, Utah, with special emphasis on the Navajo Sandstone: Salt Lake, Utah Department of Natural Resources, Technical Publication No. $78,1 \mathrm{v}$.

Marine, I.W., 1962, Water-supply possibilities at Capitol Reef National Monument, Utah: U.S. Geological Survey Water-Supply Paper 1475-G, 9 p.

McDonald, M.G., and Harbaugh, A.W., 1984, A modular three-dimensional finite-difference ground-water flow model: U.S. Geological Survey Open-File Report 83-875, 528 p.

Nelson, R.W., 1968, In-place determination of permeability distribution for heterogeneous porous media through analysis of energy dissipation: Society of Petroleum Engineers Journal, v. 8, no. 1, p. 33-42.

Potter, R.W., and Brown, D.L., 1977, The volumetric properties of aqueous sodium chloride solutions from $0^{\circ}$ to $500^{\circ} \mathrm{C}$ at pressures up to 2000 bars based on a regression of available data in the literature: U.S. Geological Survey Bulletin 1421-C, 36 p.

Rush, F.E., Whitfield, M.S., and Hart, I.M., 1982, Regional hydrology of the Green River-Moab area, Northwestern Paradox Basin, Utah: U.S. Geological Survey Open-File Report 82-107, 86 p.

Scheidegger, A.E., 1974, The physics of flow through porous media, 3 rd ed.: Toronto, University of Toronto Press, p. 78-80. 